Article

\title{
Thermodynamic-Based Exergy Analysis of Precious Metal Recovery out of Waste Printed Circuit Board through Black Copper Smelting Process
}

\author{
Maryam Ghodrat ${ }^{1, *}$, Bijan Samali ${ }^{1}$, Muhammad Akbar Rhamdhani ${ }^{2}$ (I) and Geoffrey Brooks ${ }^{2}$ \\ 1 Centre for Infrastructure Engineering, School of Computing, Engineering and Mathematics, Western Sydney \\ University, Sydney 2751, Australia; B.samali@westernsydney.edu.au \\ 2 Department of Mechanical Engineering and Product Design, Swinburne University of Technology, \\ Victoria 3122, Australia; arhamdhani@swin.edu.au (M.A.R.); gbrooks@swin.edu.au (G.B.) \\ * Correspondence: m.ghodrat@westernsydney.edu.au
}

Received: 7 March 2019; Accepted: 30 March 2019; Published: 5 April 2019

check for updates

\begin{abstract}
Exergy analysis is one of the useful decision-support tools in assessing the environmental impact related to waste emissions from fossil fuel. This paper proposes a thermodynamic-based design to estimate the exergy quantity and losses during the recycling of copper and other valuable metals out of electronic waste (e-waste) through a secondary copper recycling process. The losses related to recycling, as well as the quality losses linked to metal and oxide dust, can be used as an index of the resource loss and the effectiveness of the selected recycling route. Process-based results are presented for the emission exergy of the major equipment used, which are namely a reduction furnace, an oxidation furnace, and fire-refining, electrorefining, and precious metal-refining (PMR) processes for two scenarios (secondary copper recycling with $50 \%$ and $30 \%$ waste printed circuit boards in the feed). The results of the work reveal that increasing the percentage of waste printed circuit boards (PCBs) in the feed will lead to an increase in the exergy emission of $\mathrm{CO}_{2}$. The variation of the exergy loss for all of the process units involved in the e-waste treatment process illustrated that the oxidation stage is the key contributor to exergy loss, followed by reduction and fire refining. The results also suggest that a fundamental variation of the emission refining through a secondary copper recycling process is necessary for e-waste treatment.
\end{abstract}

Keywords: thermodynamic modeling; exergy; e-waste; secondary copper smelting; precious metal recovery; printed circuit board

\section{Introduction}

According to Rosen and Dincer [1], "exergy is an ultimate extent of work that can be generated by a flow of heat or work when it reaches an equilibrium state with an environment chosen as a reference". The exergy value is able to disclose the possibility of designing more efficient processes as well as identifying the threshold by which we can achieve these designs. The design process mainly consists of identifying and decreasing the sources of inefficiency in existing systems. The most systematic approach as recommended by many researchers (e.g., Szargut et al. [2]; Edgerton [3]) is to relate the second thermodynamic law and the impact on the environment by means of an exergy analysis. Several researchers used exergy as a thermodynamic-based index to describe the environmental impact assessment [4-19]. In 1997, Rosen and Dincer indicated that the concept of exergy could be reflected as a gauge for measuring the possible environmental impact of waste emissions [1], and the same researchers further emphasized that exergy characterized in the emission of the waste specifies how far the emissions and the considered reference environment are from each other. This also signifies the possible environmental variation as stated by Rosen and Dincer [20]. 
Other researchers such as Ji et al. [18] carried out a comprehensive comparison between standard chemical exergy and the environmental pollutant cost for contaminants that affect the atmosphere. Based on their research, the emitted exergy to the environment is considered to be an unrestrained dynamic likelihood for environmental destruction. Daniel and Rosen [9] studied the emissions generated in the lifespans of 13 automobile fuels and mapped the significance of the waste emissions exergy, which signified their imbalance with the environment.

Considering the greenhouse gas emissions as an environmental impact indicator, Rosen et al. indicated that exergy incorporated in emissions has a relatively high effect on the availability of the net exergy in the ecological community that corresponded to earth solar radiation $[7,8]$. In the meantime, Ayres et al. [4] and Ayres et al. [21] recognized that exergy might be utilized to combine waste, and waste exergy is a delegation for their possible damage to the ecosystem. These researchers recommended that the ratio between the exergy embedded in the waste outputs and that contained in the input is the most relevant benchmark for quantifying pollution.

There have also been various assessments regarding exergy losses throughout recycling that suggest improving the resource efficiency of several production processes. For example, Amini et al. [22] carried out an exergy analysis to quantify the material quality loss and efficiency of the resources in some recycling streams. They demonstrated the influence of contaminations on the amount of exergy of recovered materials. A light passenger car was chosen, and the weights of the various materials dropped in a crusher, which then went through the recycling steps and to the landfill, were calculated. The results of their study demonstrated that the amount of chemical exergy drops during various recycling steps. Some other researchers such as Ignatenko et al. [23] evaluated the efficiency of recycling systems with the aid of exergy. The same authors, Castro et al. [24] and Ignatenko et al. [23], assessed a number of automobile recycling schemes using their proposed optimization methods for recycling. Their results illustrated the ability of exergy analysis to support the evaluation of recycling systems. Castro et al. [24] proposed a technique to measure the amount of exergy and exergy losses of metal solutions through the process of recovery and recycling. They showed that the losses coming from recycling can be utilized as a key to the material quality loss and the effectiveness of the recovery system. The copper smelting industry has unique features that make the pyrometallurgical process of electronic wastes feasible [25], as it is categorized by a high consumption of thermal energy largely due to the high temperatures needed to produce cathode copper (99\% pure copper) and precious metals, which are the main purpose of the electronic waste (e-waste) treatment process. The use of electronic wastes, especially waste printed circuit boards (PCBs), in the copper smelting industry has a drawback. Their disadvantage relates to containing a big amount of plastic and polymer parts; burning them releases a considerable amount of off-gas to the environment. The current work offers an exergy-based inclusive analysis of the waste gas, metal, and oxide dusts emissions from non-renewable fuel e-waste and metal scrape consumption in a proposed e-waste treatment through a pyrometallurgical process, which is the black copper smelting or secondary copper recycling process. The exergy balance of the proposed metallurgical route has been calculated using the HSC Chemistry Sim 8.0 thermochemical package (HSC and HSC Sim 7.1\&8). The element distribution in the different inflow was predicted by the equilibrium calculations implemented by using the Fact-Sage 6.4 thermochemical package [26]. Two metal recovery scenarios (secondary copper recycling with $50 \%$ and $30 \%$ waste PCBs) have been evaluated using the developed thermodynamic model.

\section{Exergy Perception}

\section{Measurement of Exergy Losses in Recycling Process}

According to research done by Amini et al. [22], throughout the recycling of metallurgic metals, resource depletion is specifically estimated by multiplying the amount of chemical exergy of the depleted materials by the mass of that material. It is well known that the losses that occurred during the smelting process are due to contaminants. These contaminants melt in the liquefied metal and 
escalate the alloy entropy (i.e., enhancing the system disturbance); therefore, this kind of material or resource depletion is called the quality loss of the process, which is matched to an exergy loss due to the growth of the chaos within the process. Based on work done by Amini et al. [22], the losses happening during the pyrometallurgical process can be estimated by Equation (1):

$$
\Delta E_{\text {chemical }}=\left(E_{\text {chemical }}\right)_{\text {input }}-\left(E_{\text {chemical }}\right)_{\text {output }}
$$

In that, input and output denote the state of the process before and after the pyrometallurgical process, respectively. There is another kind of the loss that is linked to the amount of metals that were depleted during slag generation.

The conception of exergetic efficiency is considered as the origin of exergy balance for the input and output streams, in which $I$ is called the irreversibility [27]:

$$
E_{\text {input }}=E_{\text {output }}+I
$$

The effectiveness of exergy is the described as the percentage of the total output exergy to the total input exergy throughout the recovering process [27]:

$$
\eta=E_{\text {output }} / E_{\text {input }}
$$

Therefore, $E_{\text {output }}$ is the amount of chemical exergy of the ultimate product, where $E_{\text {input }}$ is estimated as the summation of the chemical and accumulative exergy of the materials coming into the process. In all real processes, the entropy enhances every time that an actual process happens. This phenomenon could be interpreted as a drop of the obtainable exergy in the process. The preferred condition is that the exergy depletion is as insignificant as possible after each stage of the process.

For assessing the exergy losses during recycling, the focus has been drawn to the metal and oxide dust, as these are the most relevant materials considered in metal recycling out of e-waste, from an environmental point of view. When metals recycling is carried out, various types of emissions occur. These emissions can be divided into off-gas, exhaust, and metal and oxide dust. The losses during the metal recovery through the pyrometallurgical route can be schematized in Figure 1.

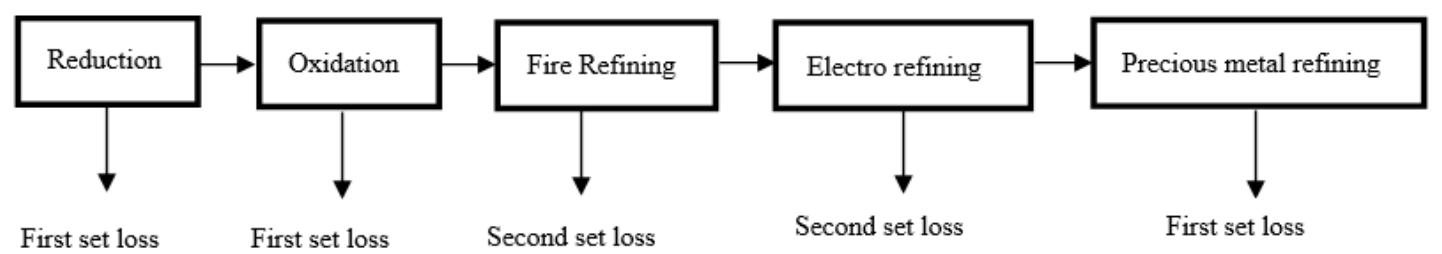

Figure 1. Exergy depletion through metal recycling out of electronic waste.

The first set of losses linked to the depleted materials that ended up in the landfill after the precious metal refining stage, and depleted in the slag through the pyrometallurgical process (reduction and oxidation stages). These losses lead to a decline in the amount of exergy in the process that is attributable to the material depletion from the process. The second set of losses arises during the refining stage (fire refining and electrorefining). When pollutants exist, they melt in the liquid metal that causes the disorder of the process to grow. Thus, the second sets of losses occur as the quality losses of the process and are correlated with an exergy loss caused by the rise of the disorder within the process. It is worthwhile to mention that this kind of loss is not related to the loss of mass. The procedure that has been considered in this study is based on the modeled process, and cannot be considered a common procedure. It is of interest to note that the exergies that are measured for a particular process-dependent model are applicable merely to that specific method. They cannot logically be correlated with exergies obtained from other process-dependent models. Finding the 
exergy of emitted wastes is the main focus of this paper; hence, the analysis employed here can detect the phases of the modeled process where the irreversibility or exergy destruction is the highest.

\section{Process Description}

To assess the influence of waste emission on the exergy content of recycled metals, an electronic waste processing plant set in a secondary copper smelting route has been considered in this study. The overall annual input materials of $110,000 \mathrm{t}$ has been chosen and fed into the plant. Secondary copper is defined as the copper that has not originated from primary sources. So, copper from any sort of metallurgical, industrial, or consumer waste is considered secondary copper. Smelting in a shaft furnace is the most common pyrometallurgical route for refining copper from secondary sources [28-31]. However, the process has its own issues, such as impurities associated with the secondary materials. Whereas the impurities related to primary smelting are much lower, this leads to different flowsheet design and operating conditions. In fact, the pyrometallurgical process of secondary copper requires a higher level of impurity removal, together with special operations for gas cleaning in order to snatch toxic emissions such as dioxins, halogens, NOx, etc.

The first stage of e-waste treatment using the secondary copper route is smelting the feed materials under reducing conditions. This usually happens in a reduction furnace, and the product is called black copper. Black copper is a middle product that then can be further purified by oxidizing to get a clean copper product. A mixture of copper scrap, electronic waste, slag, and coke is injected into the reduction furnace. Then, air is blown through the top nozzles, which causes the coke to burn and hence the smelting of other feed materials under reducing conditions.

The black copper that is generated during the reduction process has a large amount of impurities. Throughout the reduction stage, most of the impurities are separated from the liquid copper, while some of them are cut apart in the vapor phase (dust of metals and their oxides).

In the course of the oxidation of black copper, which could be conducted in the same furnace or in a separate oxidation furnace, some impurities such as $\mathrm{Zn}, \mathrm{Sn}$, and $\mathrm{Pb}$ are taken out in the form of their oxides into the slag phase. Some other impurities such as lead and tin are separated into the gas phase and go through the filtering plant [25,32].

In the fire-refining stage, air and a reducing agent such as hydrocarbon are added to remove any existing oxides. Air is blown through molten metals, which oxidizes the existing impurities and removes sulfur. In the fourth stage, which is the electrorefining stage, an electrolytic cell is employed to separate copper and other metals. Copper in the impure anode is dissolved into an electrolyte to be coated onto a copper cathode. Insoluble impurities such as precious metals ( $\mathrm{Ag}$ and $\mathrm{Au}$ ), platinum group metals, $\mathrm{Sn}$, and some minor amount of $\mathrm{Pb}$ in the electrolyte dropped to the bottom of the cell as anode slimes. The rest of the impure elements such as $\mathrm{As}, \mathrm{Bi}, \mathrm{Ni}, \mathrm{Sb}$, and Fe are partly or completely solvable in the electrolyte. The main reason for that is that the electrochemical properties of these elements are much lower than those of the electrorefining cell voltage; hence, they are not able to plate onto the cell.

The next stage of the process is electrowinning. In the electrowinning process, impure copper is leached in a copper sulfate solution and pure copper is recovered as a result. Lead or titanium acts as an insoluble anode, and steel or copper sheets act as cathodes in the process. The removal of copper from the solution and its deposition on the cathode happens in a similar way as in the electrorefining process. In the precious metal refining stage, valuable metals (mainly Au and Ag) are separated into the slime or sludge and deposited on the electrolytic cell. Then, the sludge goes through additional processing to recover $\mathrm{Ag}$ and $\mathrm{Au}$. The flow sheet of the selected e-waste processing route is shown in Figure 2. 


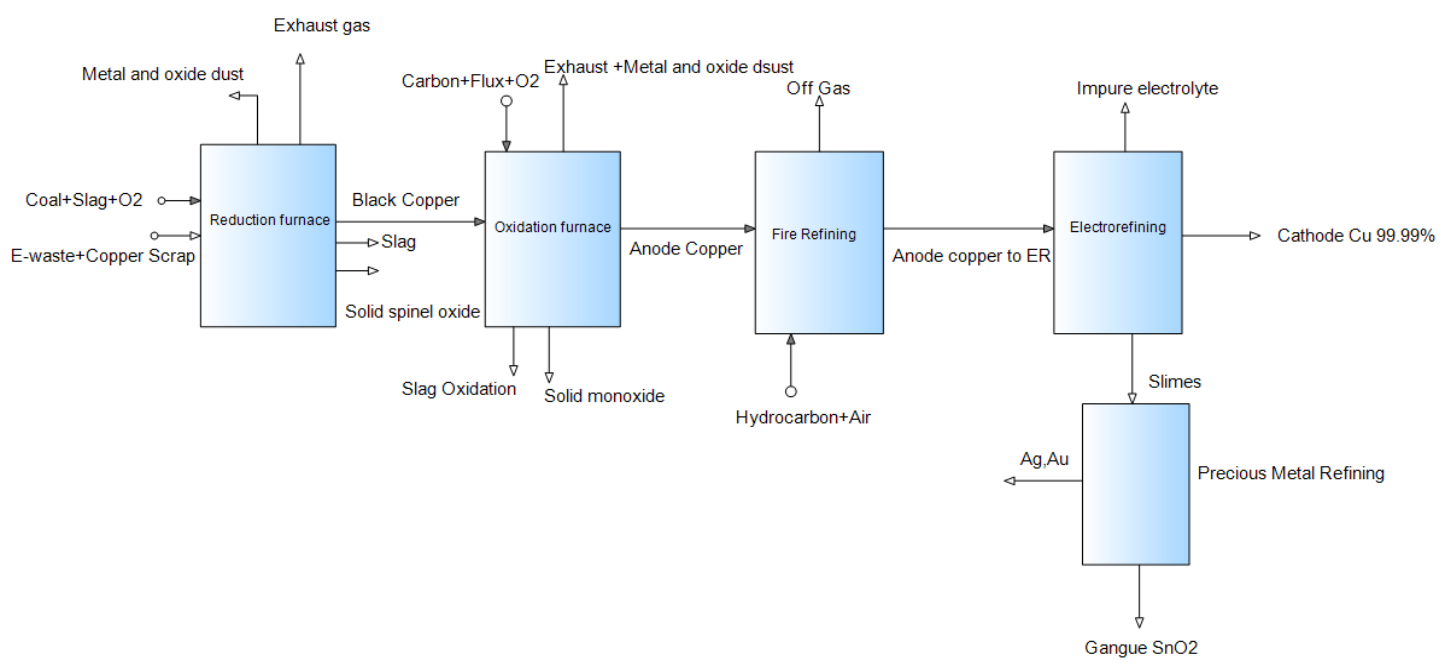

Figure 2. Flowsheet of the chosen process.

\section{Methodology}

The exergy balance of the proposed e-waste treatment process via secondary copper smelting has been developed using the HSC Chemistry thermochemical package (HSC and HSC Sim 7.1\&8). This includes the modeling of black copper smelting process while adding $50 \%$ and $30 \%$ electronic waste of the total feed throughput into the feed.

The Fact-Sage 6.4 thermochemical package [26] is employed to calculate different element distribution in various flow streams (off gas, slag, and molten metal). The thermodynamic databases that exist in Fact-Sage include two main types, namely the compound database and the solution database. The compound database is employed for pure substance, and the solution database covered the adjusted parameters for solutions such as molten metals, liquid, or solid oxide solutions.

The Equilib module of Fact-Sage, which uses the Gibbs free-energy minimization algorithm, is used in this study. The Gibbs energy minimization mode calculates all of the equilibrium phase transitions by employing the user-defined compound and solution data. This module is basically utilized to predict the thermodynamically stable phases under assumed settings.

\section{Databases}

FactSage contains various optimized databanks for alloys solutions, slags, and liquid and solid oxides. In this study, optimized databases for copper-rich multicomponent systems and their correlated slags are adopted. "FactPS" and "FToxid" are used for the pure substances and liquid/solid oxide solutions, respectively. The FScopp database is used for copper alloy, and the SGnobl database used for evaluating the thermodynamic parameters of noble metals and their alloys.

The multicomponent structures consist of $\mathrm{CaO}, \mathrm{SiO}_{2}, \mathrm{Fe}_{2} \mathrm{O}_{3}, \mathrm{FeO}$, and $\mathrm{Al}_{2} \mathrm{O}_{3}$ modified and used for the entire collection of compounds between $300-1700{ }^{\circ} \mathrm{C}$. The liquid state oxides such as slag are analyzed by means of an amended quasichemical model that resolves the short-range ordering of compounds [25]. $\mathrm{Cu}_{2} \mathrm{O}$ is assumed to an ideal solution and act as an elemental component of the slag. The behavior of liquid phase such as copper solution is signified by simplified polynomial expressions that are usable for a copper-rich liquid domain in temperature range of 300 to $1700{ }^{\circ} \mathrm{C}$ [25]. The equilibrium calculations are carried out for temperatures extending from 1100 to $1600{ }^{\circ} \mathrm{C}$ with partial pressures of oxygen changing from $10^{-7}$ to $10^{-10}$ atm [25]. For modeling purposes, difference oxygen partial pressures are set manually, and carbon is included respectively to reach the essential reducing condition objective.

For the oxidation stage of the process, the thermodynamic analysis is performed using multi-phase equilibrium calculations. This is done by including oxygen cumulatively ( $250 \mathrm{~kg}$ of oxygen added at each stage). This enables the tracing of slag formation, enhancing the purity of liquid copper, and 
carrying copper to the slag during the process's progression. The analysis of the oxidation stage happened at temperatures between $1000-1600{ }^{\circ} \mathrm{C}$ and pressure of $1 \mathrm{~atm}$. Then, copper rich in a liquid state is separated and carried to the next stage of the process, which is fire refining. The equilibrium in the fire-refining phase of the process is calculated between the $\mathrm{Cu}$-rich loquacious phase, the gashouse phase (air), and the reducing agents (hydrocarbon), which ended up becoming anode grade copper. The copper amount produced at the end of this stage of the process contained some degree of impurities such as $\mathrm{Sn}, \mathrm{Ni}, \mathrm{Ag}$, and $\mathrm{Au}$, which are separated in the electrorefining process. The analysis of this stage is conducted using the data from the literature.

Regarding the precious metal refining stage, which is the final stage of the process, the databases have not yet been optimized. For this reason, modeling the comportment of precious metals and aspects such as the partition ratio of precious metals in the slag and in the final product are carried out by gathering information from industry and available information in the literature.

The outcomes of the present analysis reported in this study merely rely on the thermodynamic calculations, and hence do not include the kinetics parameters that can have a significant influence on the total metal recovery in the actual process.

Through the thermodynamic analysis, it is estimated that temperatures of more than $1300{ }^{\circ} \mathrm{C}$ and an oxygen fractional pressure of $10^{-8}$ are needed for the proposed e-waste processing route [25]. Carbon that exists in the e-waste provides supplementary heat and reductant (such as $\mathrm{CO}$ ) throughout the reduction phase of the process, and therefore can replace a proportion of the coke that is used as an input material. In this study, exergy analysis is conducted for two scenarios. In the " $50 \%$ e-waste in the feed" scenario, $12 \mathrm{t} / \mathrm{h}$ of input material consisting of $5.94 \mathrm{t}$ of e-waste (waste PCBs), $6 \mathrm{t}$ of copper scrap, 0.08 tof coal, and $0.42 \mathrm{t}$ of slag is fed into the reduction furnace.

The main feed materials composition that is employed in this study is presented in Tables 1 and 2. The compositions of these feed materials were given before in the work of Ghodrat et al. [25].

Table 1. Metal oxides, metallurgical coke, and slag composition utilized in the input, as publihsed by Ghodrat et al. [25].

\begin{tabular}{ccccccc}
\hline Metal Oxide & $\mathbf{C u}$ & $\mathbf{C u}_{\mathbf{2}} \mathbf{O}$ & $\mathbf{S n O}_{2}$ & $\mathbf{P b O}$ & $\mathbf{Z n O}$ & $\mathbf{N i O}$ \\
\hline wt $\%$ & 70 & 7 & 5 & 8 & 5 & 5 \\
Metallurgical coke elements & $\mathrm{C}$ & $\mathrm{H}_{2} \mathrm{O}$ & $\mathrm{S}$ & $\mathrm{Al}_{2} \mathrm{O}_{3}$ & $\mathrm{FeO}$ & \\
wt $\%$ & 90 & 5 & 0.8 & 2 & 2.2 & \\
slag & $\mathrm{FeO}$ & $\mathrm{CaO}$ & $\mathrm{SiO}_{2}$ & & & \\
wt $\%$ & 45 & 17 & 38 & & & \\
\hline
\end{tabular}

Table 2. Chosen compositions of PCB employed in the input, as published by Ghodrat et al. [25].

\begin{tabular}{ccccccccccccccc}
\hline Element & $\mathbf{C u}$ & $\mathbf{A g}$ & $\mathrm{Au}$ & $\mathrm{Al}$ & $\mathrm{Zn}$ & $\mathbf{P b}$ & $\mathrm{Fe}$ & $\mathrm{Sn}$ & $\mathbf{N i}$ & $\mathbf{B r}$ & $\mathbf{N}$ & $\mathbf{C}$ & $\mathbf{A l}_{2} \mathbf{O}_{3}$ & $\mathrm{SiO}_{2}$ \\
\hline $\mathrm{wt}^{2} \%$ & 20.6 & 0.2 & 0.1 & 5 & 4 & 6 & 8.6 & 4 & 2 & 4 & 5 & 10 & 6 & 23.5 \\
\hline
\end{tabular}

In "30\% e-waste in the feed" scenario, $12 \mathrm{t} / \mathrm{h}$ input material consisting of $3.7 \mathrm{t}$ of electronic waste (waste PCBs), $8.25 \mathrm{t}$ of copper scrap, $0.08 \mathrm{t}$ of coal, and $0.42 \mathrm{t}$ of slag is fed into the reduction furnace. An overview of the entire modeling approach has been shown in Figure 3. In this gate-to-gate analysis, an exergy investigation has been conducted to assess the broadly used secondary copper recycling process by replacing part of the copper scrap with waste PCBs. The variable was the different percentage of e-waste in the feed material. A proposed flow sheet for the exergy balance of valuable metals recycling from waste printed circuit boards through secondary copper smelting is developed for two scenarios (50 $\mathrm{wt} \%$ and $30 \mathrm{wt} \%$ e-waste in the feed) using HSC Chemistry and shown in Figures 4 and 5 , respectively. 

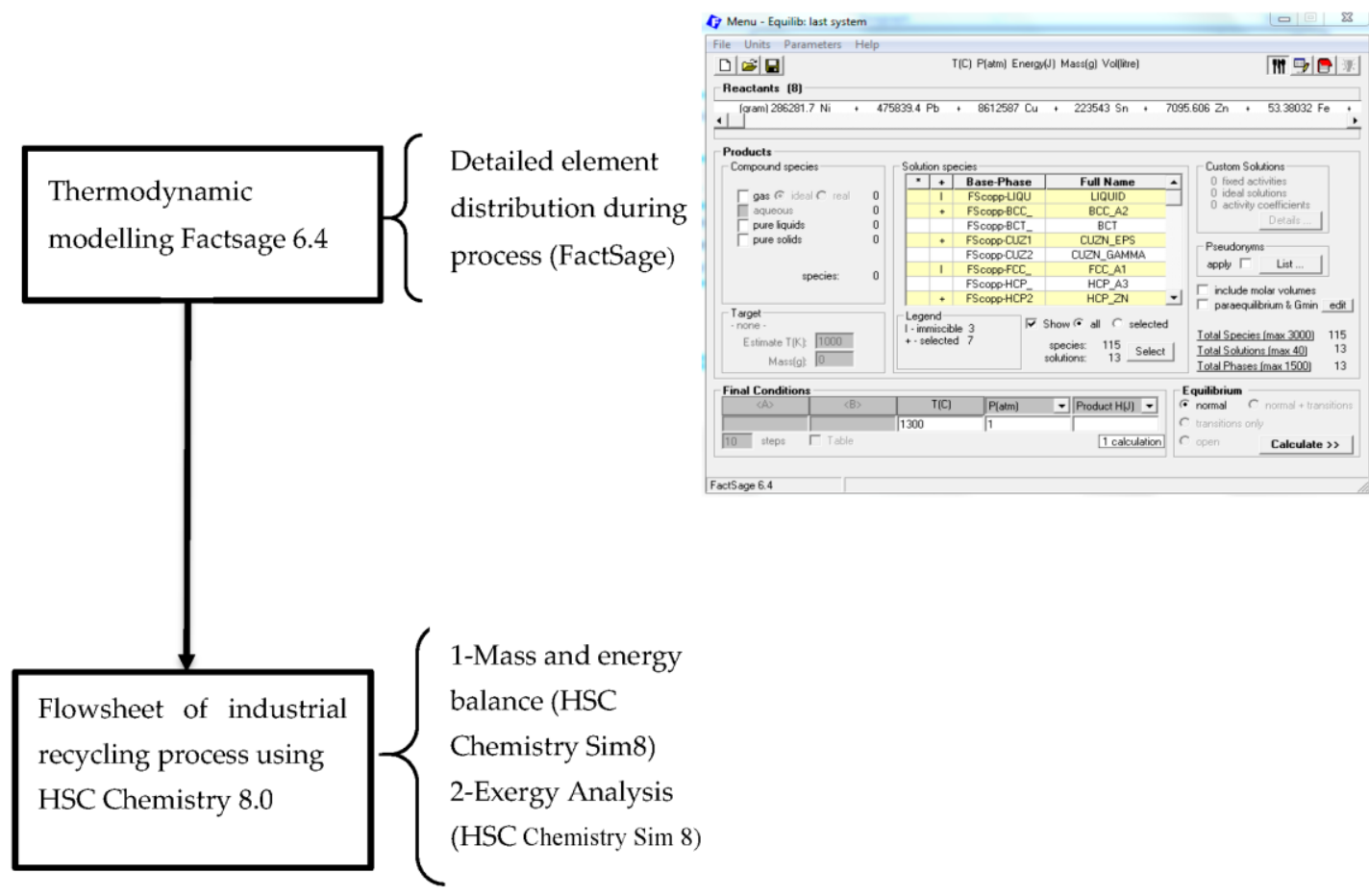

Figure 3. Flow chart of the procedure performing the exergy analysis.

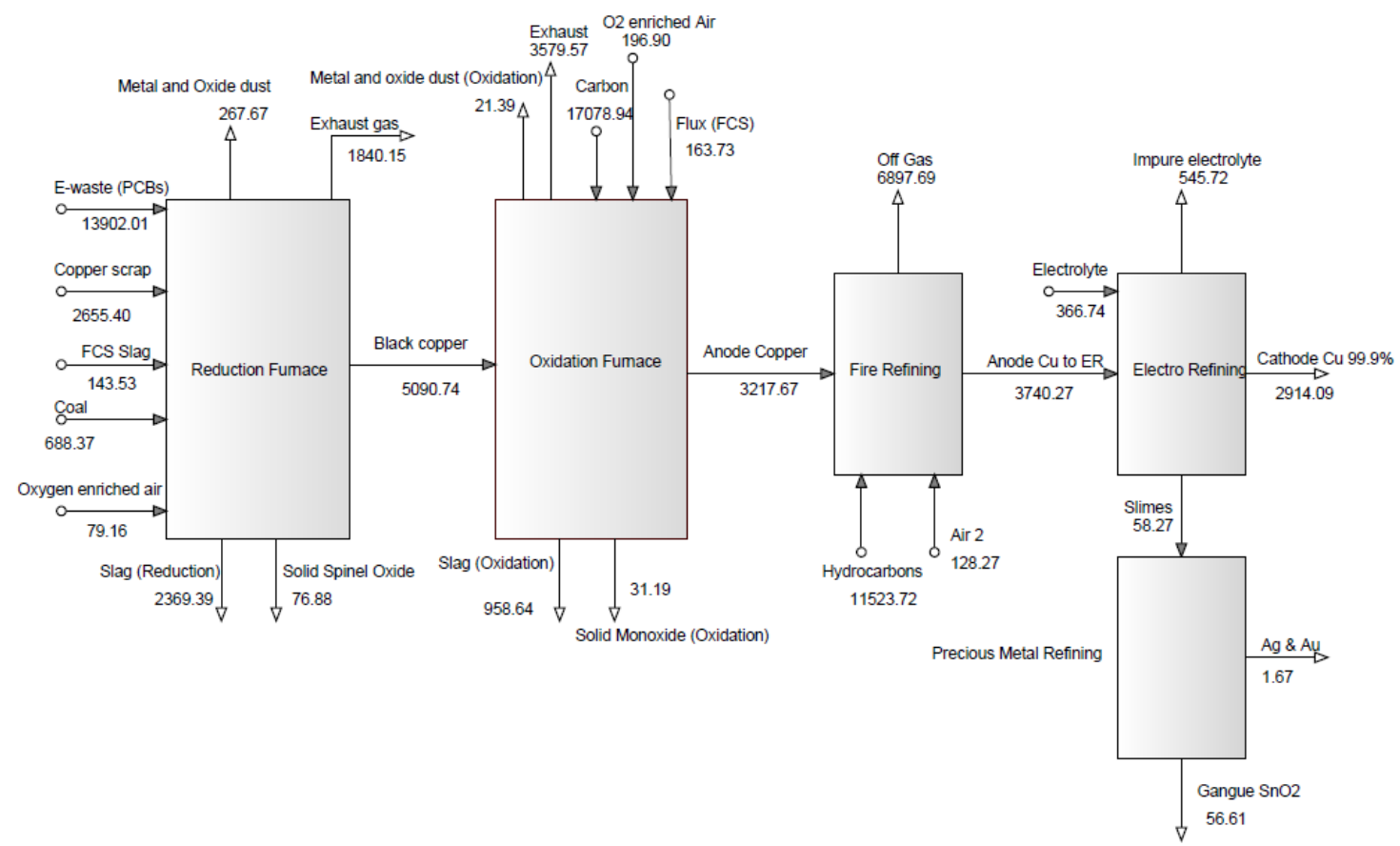

Figure 4. Total exergy balance (kWh), 50\% e-waste in the throughput. 


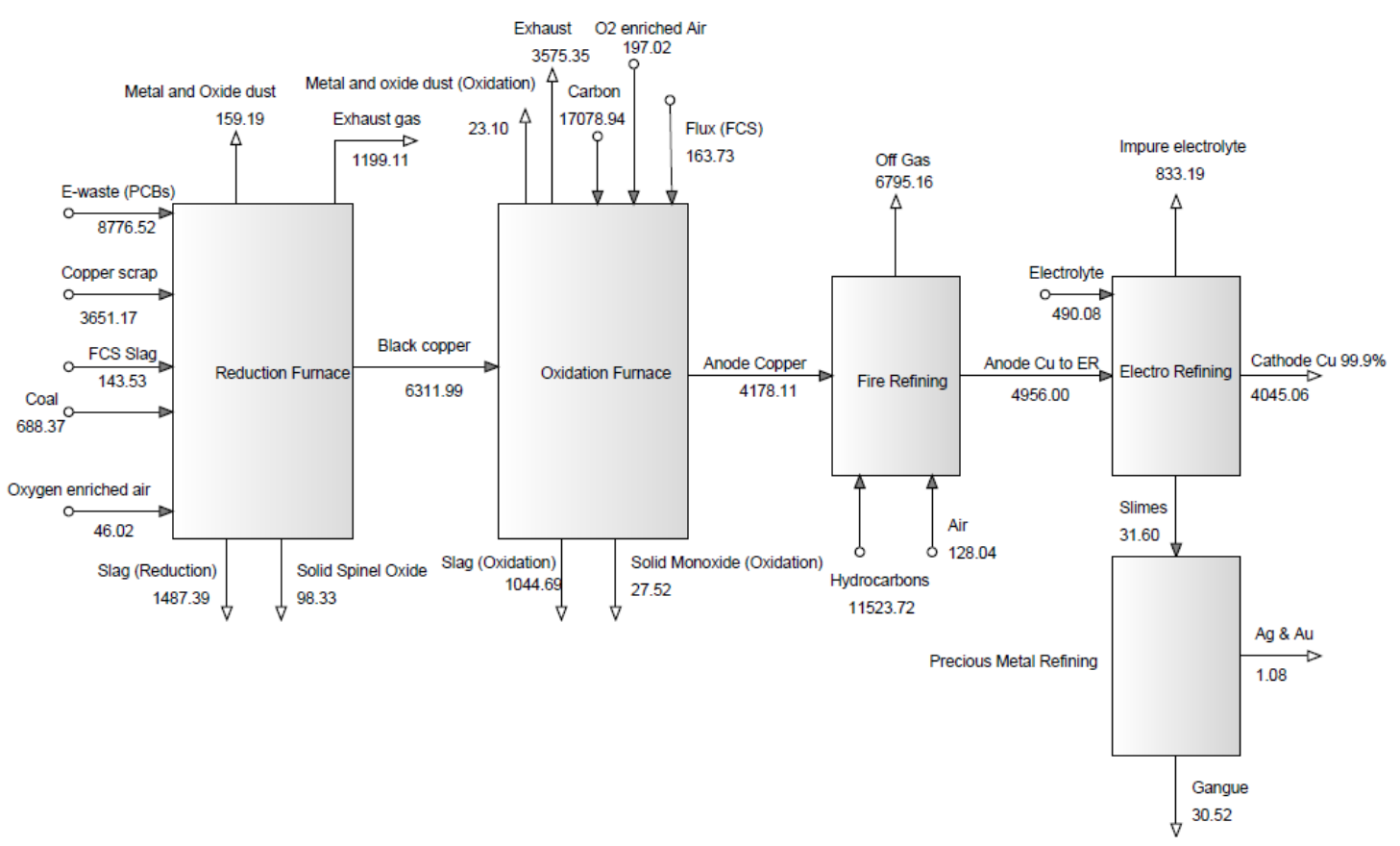

Figure 5. Total exergy balance (kWh), 30\% e-waste in the throughput.

\section{Results and Discussion}

The element distribution in the output and input flows was estimated using a mixture of equilibrium modeling and data gathered from the relevant industries and the literature. As mentioned earlier, in this study, the Equilib module of Factsage using the Gibbs free-energy minimization mode and thermodynamic function of HSC chemistry is used for exergy calculation.

Specified compounds of chemical elements react to attain an equilibrium state. First, the reactants are defined; then, the compound and solution products are specified, and at the end, the final operational conditions of the process are set.

Based on the HSC Chemistry thermochemical database, the identified products in different phases include pure solids substance in the gas phase, spinel in the slag phase, and matte in the copper alloy solution phase. The distribution of elements in different phases was calculated by the "Dist" function of HSC Chemistry Sim 8 software and presented in Table 3.

Aluminum is a part of e-waste that is casted off to slag; however, this can lead to a higher slag viscosity and loss of the copper. About $50 \%$ of cobalt and a relatively high percentage of $\mathrm{Ni}$ are disseminated into copper phases.

In the fourth stage, which is electrorefining, $\mathrm{Ni}$ dissolves and is discarded in the electrolyte refinement route, although some proportion of the nickel concludes in the anode slime. $\mathrm{Pb}, \mathrm{Zn}$, and $\mathrm{Sn}$ are dropped in slag or off-gas, particularly in smelting and converting; a low percentage of these turn out to be in the blister copper. $\mathrm{Pb}$ may also be separated in the anode furnace using substances such as silica flux [30]. $\mathrm{Pb}, \mathrm{Zn}$, and $\mathrm{Sn}$ may also cut off in anode slime through electrorefining [30].

For the duration of smelting, Bi and As are scattered in the metal dusts phase, and can be recuperated via hydrometallurgical routes. The concentration of $\mathrm{Sb}$ and Bi needed to be controlled carefully in the electrolyte. The main reason is the presence of a high proportion of $\mathrm{As}$ to $\mathrm{Sb}$ and $\mathrm{Bi}$; the molar ratio blocks the formation of floating slimes in the electrolyte. 
Table 3. Distribution of elements between different phases.

\begin{tabular}{|c|c|c|c|}
\hline \multicolumn{4}{|c|}{ Reduction } \\
\hline Solid/Gas & Gaseous & Solid & Liquid \\
\hline Metal and Oxide dust & Exhaust Gas & Slag & Black Copper \\
\hline $\mathrm{Zn}, \mathrm{Pb}, \mathrm{CuBr}, \mathrm{PbBr}(\mathrm{g})$ & $\mathrm{CO}_{2}(\mathrm{~g}), \mathrm{N}_{2}(\mathrm{~g})$ & $\mathrm{Al}_{2} \mathrm{O}_{3}(\mathrm{l}), \mathrm{SiO}_{2}, \mathrm{CaO}, \mathrm{FeO}$ & $\mathrm{Ni}, \mathrm{Pb}, \mathrm{Cu}(\mathrm{l})$ \\
\hline $\mathrm{PbO}, \mathrm{SnO}, \mathrm{HBr}(\mathrm{g}), \mathrm{PbS}$ & $\mathrm{CO}(\mathrm{g}), \mathrm{H}_{2} \mathrm{O}(\mathrm{g})$ & $\mathrm{Fe}_{2} \mathrm{O}_{3}, \mathrm{PbO}, \mathrm{ZnO}, \mathrm{NiO}, \mathrm{SnO}(\mathrm{l})$ & $\mathrm{Sn}, \mathrm{Zn}, \mathrm{Fe}$ \\
\hline $\mathrm{Au}, \mathrm{NiBr}(\mathrm{g}), \mathrm{NiBr}_{2}, \mathrm{AgBr}$ & $\mathrm{SO}_{2}(\mathrm{~g}), \mathrm{H}_{2}(\mathrm{~g})$ & $\mathrm{Cu}_{2} \mathrm{O}(\mathrm{l}), \mathrm{FeS}, \mathrm{PbS}$ & $\mathrm{Au}, \mathrm{Ag}, \mathrm{In}$ \\
\hline \multirow[t]{3}{*}{$\begin{array}{l}\mathrm{FeBr}_{2}, \mathrm{InBr}, \mathrm{GeO}, \mathrm{SnS}, \mathrm{Br} \\
\mathrm{ZnBr}_{2}, \mathrm{PbBr}_{2}, \mathrm{SnBr}_{2}\end{array}$} & $\mathrm{SO}(\mathrm{g})$ & $\begin{array}{c}\mathrm{ZnS}, \mathrm{NiS}, \mathrm{Cu}_{2} \mathrm{~S}, \mathrm{SnS}, \mathrm{GeO}_{2} \\
\mathrm{AgO}, \mathrm{Ta}\end{array}$ & $\mathrm{Ge}, \mathrm{Pd}$ \\
\hline & & Solid Spinel Oxide & \\
\hline & & $\begin{array}{c}\mathrm{NiO}, \mathrm{ZnO}_{,} \mathrm{Fe}_{3} \mathrm{O}_{4} \\
\mathrm{Al}_{2} \mathrm{O}_{3}\end{array}$ & \\
\hline \multicolumn{4}{|c|}{ Oxidation } \\
\hline Solid/Gas & Gaseous & Solid & Liquid \\
\hline Metal and Oxide Dust & Exhaust Gas & Slag & Anode Copper to Fire Refining \\
\hline \multirow{2}{*}{$\begin{array}{l}\mathrm{Zn}, \mathrm{Pb}, \mathrm{PbO}, \mathrm{SnO}, \mathrm{PbS} \\
\mathrm{Au}, \mathrm{GeO}, \mathrm{SnS}\end{array}$} & $\begin{array}{l}\mathrm{CO}_{2}(\mathrm{~g}), \mathrm{N}_{2}(\mathrm{~g}) \\
\mathrm{CO}(\mathrm{g}), \mathrm{H}_{2} \mathrm{O}(\mathrm{g})\end{array}$ & $\begin{array}{c}\mathrm{FeO}, \mathrm{CaO}, \mathrm{SiO}_{2}, \mathrm{Fe}_{2} \mathrm{O}_{3} \\
\mathrm{PbO}, \mathrm{ZnO}, \mathrm{NiO}(\mathrm{l}), \mathrm{SnO}(\mathrm{l})\end{array}$ & $\mathrm{Ni}, \mathrm{Pb}, \mathrm{Cu}(\mathrm{l}), \mathrm{Sn}, \mathrm{Zn}$ \\
\hline & $\begin{array}{l}\mathrm{SO}_{2}(\mathrm{~g}), \mathrm{H}_{2}(\mathrm{~g}) \\
\mathrm{SO}(\mathrm{g}), \mathrm{O}_{2}(\mathrm{~g})\end{array}$ & $\mathrm{Cu}_{2} \mathrm{O}(\mathrm{l}), \mathrm{GeO}_{2}, \mathrm{AgO}$ & $\mathrm{Fe}, \mathrm{Au}, \mathrm{Ag}, \mathrm{In}, \mathrm{Ge}, \mathrm{Pd}$ \\
\hline & & Solid Monoxide & \\
\hline & & $\begin{array}{c}\mathrm{Fe}_{3} \mathrm{O}_{4}, \mathrm{CaO} \\
\mathrm{ZnO}, \mathrm{NiO} \\
\mathrm{SnO}_{2}\end{array}$ & \\
\hline \multicolumn{4}{|c|}{ Fire Refining } \\
\hline \multirow[t]{5}{*}{ Solid/Gas } & Gaseous & Solid & Liquid \\
\hline & Off Gas & & Anode Cu to Electro Refining \\
\hline & \multirow{4}{*}{$\begin{array}{c}\mathrm{H}_{2}(\mathrm{~g}), \mathrm{Co}(\mathrm{g}), \mathrm{H}_{2} \mathrm{O}(\mathrm{g}) \\
\mathrm{CO}_{2}(\mathrm{~g}), \mathrm{Pb}, \mathrm{Cu}, \mathrm{Ag}, \mathrm{Zn} \\
\mathrm{CH}_{4}(\mathrm{~g}), \mathrm{SnO}(\mathrm{g}), \mathrm{GeO}(\mathrm{g}) \\
\mathrm{Ni}, \mathrm{Fe}, \mathrm{N}_{2}(\mathrm{~g})\end{array}$} & & $\begin{array}{l}\mathrm{Ag}, \mathrm{Au}, \mathrm{C} \\
\mathrm{Cu}(\mathrm{l}), \mathrm{Fe}, \mathrm{Ge}\end{array}$ \\
\hline & & & In, $\mathrm{Ni}, \mathrm{Pb}, \mathrm{Pd}$ \\
\hline & & & $\mathrm{Sn}, \mathrm{Zn}$ \\
\hline \multirow{6}{*}{ Solid/Gas } & & lectrorefining & \\
\hline & \multicolumn{2}{|l|}{ Gaseous } & Liquid \\
\hline & & Impure Electrolyte & Cathode Cu 99.9\% \\
\hline & & \multirow[t]{3}{*}{$\begin{array}{c}\mathrm{H}_{2} \mathrm{O}, \mathrm{H}_{2} \mathrm{SO}_{4}, \mathrm{Ni}, \mathrm{As} \\
\mathrm{Ag}, \mathrm{Au}, \mathrm{C}, \mathrm{Cu}, \mathrm{Fe}, \mathrm{Ge} \\
\mathrm{In}, \mathrm{Pb}, \mathrm{Pd}, \mathrm{Sn}, \mathrm{Zn}\end{array}$} & $\begin{array}{l}\mathrm{Ag}, \mathrm{Au}, \mathrm{C}, \mathrm{Cu}(\mathrm{l}), \mathrm{Fe}, \mathrm{Ge} \\
\mathrm{In}, \mathrm{Ni}, \mathrm{Pb}, \mathrm{Pd}, \mathrm{Sn}, \mathrm{Zn}, \mathrm{S}\end{array}$ \\
\hline & & & Slimes \\
\hline & & & $\begin{array}{c}\mathrm{Ag}, \mathrm{Au}, \mathrm{C} \\
\mathrm{Cu}, \mathrm{Fe}, \mathrm{Ge}, \mathrm{In} \\
\mathrm{Ni}, \mathrm{Pb}, \mathrm{Pd}, \mathrm{Sn} \\
\mathrm{Zn}, \mathrm{As}\end{array}$ \\
\hline \multicolumn{4}{|c|}{ Precious Metal Refining } \\
\hline \multirow[t]{3}{*}{ Solid/Gas } & Gaseous & Solid & Liquid \\
\hline & & Gangue & Precious Metals \\
\hline & & $\begin{array}{c}\mathrm{Ag}, \mathrm{Au}, \mathrm{C}, \mathrm{Cu}, \mathrm{Fe}, \mathrm{Ge}, \mathrm{In}, \mathrm{Ni}, \mathrm{Pb} \\
\mathrm{Pd}, \mathrm{Sn}, \mathrm{Zn}, \mathrm{As}\end{array}$ & $\mathrm{Ag}, \mathrm{Au}$ \\
\hline
\end{tabular}

The results of the thermodynamic equilibrium calculations can help us understand on a chemical level the influence of different parameters such as the composition of materials, reducing agents, the oxidation process, pressure, or temperature on the composition of the resultant materials and the properties such as exergy quantity and losses during the studied process. Equilibrium calculations are employed to compute the steady phase accumulations based on the different solution composition as well as simulate the stable phase assembly, and hence evaluate the effect of the chemical composition on our recycling system. This thermodynamic calculation can also, in combination with an HSC model, be used to follow the changes (including changes in the chemical and total exergy) during different stages of the process. However, as many of the kinetic data regarding exergy calculation are not (yet) available, it is essential to comprehend the importance of conducting such studies. Thus far, 
thermodynamic equilibrium calculations have been applied mainly to mass and energy balance calculations, and not exergy evaluation. However, the approach is equally valid for primary copper smelting systems based on the primary input materials, and is expected to further the development of new waste materials and blends.

The values of the incoming and outgoing exergies of five process units involved in the e-waste treatment through the secondary copper smelting process are compared for the two considered scenarios (50\% and 30\% e-waste in the feed material) in Table 4 . The exergy values of materials going into the reduction, oxidation, fire-refining, and electrorefining processes are shown in Tables $5-8$, respectively.

The exergy values of molten copper, dust, slag, copper, and precious metal in sludge, off gases, impure electrolyte, and gangue are shown in Table 8 on a chemical element basis coming out of the reduction, oxidation, fire refining, electrorefining, and precious metal refining processes.

Table 4. Values of exergies of process units involved in electronic waste (e-waste) treatment through the copper recycling process.

\begin{tabular}{|c|c|c|c|c|c|c|}
\hline \multicolumn{3}{|c|}{ Inlet Exergies } & \multicolumn{4}{|c|}{ Outlet Exergies } \\
\hline & Source & $\begin{array}{c}\begin{array}{c}\text { Exergy } \\
\text { (Total) } \\
\text { (kWh)-50\% }\end{array} \\
\end{array}$ & $\begin{array}{c}\text { Exergy } \\
\text { (Total) } \\
(\mathrm{kWh})-30 \%\end{array}$ & Source & $\begin{array}{c}\text { Exergy } \\
\text { (Total) } \\
(\mathrm{kWh})-50 \%\end{array}$ & $\begin{array}{l}\text { Total Exergy } \\
\text { (kWh)-30\% }\end{array}$ \\
\hline \multirow{5}{*}{ Reduction } & E-waste & 13,902 & 8776 & $\begin{array}{c}\text { Metal and oxide } \\
\text { dust }\end{array}$ & 228.33 & 129 \\
\hline & $\begin{array}{c}\text { Copper scrape } \\
\text { FCS }\end{array}$ & 2655 & 3651 & Exhaust gas & 791.40 & 529 \\
\hline & $\begin{array}{l}\text { (ferrous-calcia-silica) } \\
\text { Slag }\end{array}$ & 143 & 143 & Slag & 1135.29 & 716 \\
\hline & Coal & 688 & 688 & Solid spinel oxide & 35.96 & 51 \\
\hline & $\mathrm{O}_{2}$ & 79 & 46 & & & \\
\hline \multirow{4}{*}{ Oxidation } & Carbon & 17,078 & 17,078 & Slag & 542.83 & 610 \\
\hline & $\mathrm{O}_{2}$ enriched air & 196 & 197 & Solid monoxide & 12.91 & 12 \\
\hline & Flux (FCS) & 163 & 164 & Exhaust & 958.36 & 958 \\
\hline & & & & $\begin{array}{l}\text { Metal and oxide } \\
\text { dust }\end{array}$ & 14.92 & 16 \\
\hline \multirow{2}{*}{ Fire refining } & Hydrocarbon & $14,701.78$ & 11,523 & Off gas & 3956.67 & 3881 \\
\hline & Air & 128.27 & 128 & & & \\
\hline \multirow{2}{*}{ Electrorefining } & Electrolyte & 360.23 & 482 & Impure electrolyte & 545.72 & 833 \\
\hline & & & & Cathode Cu 99.9\% & 2914.09 & 3825 \\
\hline \multirow{2}{*}{$\begin{array}{l}\text { Precious metal } \\
\text { refining }\end{array}$} & Slimes & 58.27 & 31.60 & $\mathrm{Ag}, \mathrm{Au}$ & 1.67 & 1.2 \\
\hline & & & & Gangue & 56.61 & 30.52 \\
\hline
\end{tabular}

Table 5. Exergy values of materials injected into the reduction furnace.

\begin{tabular}{|c|c|c|c|c|c|}
\hline Chemical Component & $\begin{array}{c}\text { Chemical } \\
\text { Exergy } \\
(\mathbf{k W h})-50 \%\end{array}$ & $\begin{array}{c}\text { Chemical } \\
\text { Exergy } \\
(\mathbf{k W h})-30 \%\end{array}$ & Chemical Component & $\begin{array}{c}\text { Chemical } \\
\text { Exergy } \\
(\mathrm{kWh})-50 \%\end{array}$ & $\begin{array}{c}\text { Chemical } \\
\text { Exergy } \\
(\mathbf{k W h})-30 \%\end{array}$ \\
\hline $\mathrm{Cu}$ (E-waste stream) & 722.49 & 456.12 & $\mathrm{Cu}_{2} \mathrm{O}$ & 97.14 & 133.57 \\
\hline $\begin{array}{c}\mathrm{Cu} \text { (copper scarp } \\
\text { stream) }\end{array}$ & 2432.62 & 3344.85 & $\mathrm{SnO}_{2}$ & 22.29 & 30.65 \\
\hline $\mathrm{Ag}$ & 1.52 & 0.96 & $\mathrm{PbO}$ & 37.42 & 51.45 \\
\hline $\mathrm{Au}$ & 0.21 & 0.13 & $\mathrm{ZnO}$ & 29.22 & 40.18 \\
\hline $\mathrm{Al}$ & 2715.80 & 1714.52 & $\mathrm{NiO}$ & 36.71 & 50.47 \\
\hline $\mathrm{Zn}$ & 347.97 & 219.68 & FeO (FCS slag stream) & 96.54 & 96.54 \\
\hline $\mathrm{Pb}$ & 119.12 & 75.20 & $\mathrm{CaO}$ & 45.20 & 45.20 \\
\hline $\mathrm{Fe}$ & 977.73 & 617.26 & $\mathrm{SiO}_{2}$ & 1.79 & 1.79 \\
\hline Sn & 306.84 & 193.71 & $\mathrm{C}^{2}$ & 683.16 & 683.16 \\
\hline $\mathrm{Ni}$ & 136.34 & 86.08 & $\mathrm{H} 2 \mathrm{O}$ & 0.06 & 0.06 \\
\hline $\mathrm{Br}$ & 41.80 & 26.39 & $\mathrm{~S}$ & 3.38 & 3.38 \\
\hline C & 5636.05 & 3558.11 & $\mathrm{Al}_{2} \mathrm{O}_{3}$ & 0.87 & 0.87 \\
\hline $\mathrm{SiO}_{2}$ & 16.00 & 10.10 & $\mathrm{FeO}$ (Coal stream) & 0.90 & 0.90 \\
\hline In & 0.13 & 0.08 & $\mathrm{O}_{2}$ & 69.07 & 40.16 \\
\hline $\mathrm{Ge}$ & 0.25 & 0.16 & $\mathrm{~N}_{2}$ & 10.09 & 5.87 \\
\hline $\mathrm{Ta}$ & 0.18 & 0.11 & & & \\
\hline $\mathrm{Pd}$ & 0.06 & 0.04 & & & \\
\hline
\end{tabular}


Table 6. Exergy values of materials going into the oxidation furnace.

\begin{tabular}{|c|c|c|c|c|c|}
\hline Chemical Component & $\begin{array}{c}\text { Chemical } \\
\text { Exergy } \\
(\mathbf{k W h})-50 \%\end{array}$ & $\begin{array}{c}\text { Chemical } \\
\text { Exergy } \\
\text { (kWh)-30\% }\end{array}$ & Chemical Component & $\begin{array}{c}\text { Chemical } \\
\text { Exergy } \\
\text { (kWh)-50\% }\end{array}$ & $\begin{array}{c}\text { Chemical } \\
\text { Exergy } \\
(\mathrm{kWh})-30 \%\end{array}$ \\
\hline $\mathrm{O}_{2}(\mathrm{~g})\left(\mathrm{O}_{2}\right.$ enriched Air stream) & 171.81 & 172.05 & $\mathrm{Cu}(\mathrm{l})$ (black copper stream) & 3155.42 & 4056.26 \\
\hline $\mathrm{N}_{2}(\mathrm{~g})\left(\mathrm{O}_{2}\right.$ enriched Air stream $)$ & 25.09 & 24.98 & Sn (black copper stream) & 593.65 & 604.12 \\
\hline $\mathrm{FeO}$ & 55.29 & 55.29 & Zn (black copper stream) & 23.13 & 16.22 \\
\hline $\mathrm{CaO}$ & 104.93 & 104.93 & Fe (black copper stream) & 4.39 & 5.36 \\
\hline $\mathrm{SiO} 2$ & 3.51 & 3.51 & Au (black copper stream) & 0.21 & 0.13 \\
\hline $\mathrm{C}$ & $17,078.94$ & $17,078.94$ & Ag (black copper stream) & 1.49 & 0.96 \\
\hline Ni (black copper stream) & 378.41 & 437.47 & In (black copper stream) & 0.04 & 0.04 \\
\hline \multirow[t]{2}{*}{$\mathrm{Pb}$ (black copper stream) } & 64.06 & 86.79 & Ge (black copper stream) & 0.15 & 0.12 \\
\hline & & & Pd (black copper stream) & 0.06 & 0.04 \\
\hline
\end{tabular}

Table 7. Exergy values of materials going into the fire-refining stage.

\begin{tabular}{cccccc}
\hline Chemical Component & $\begin{array}{c}\text { Chemical } \\
\text { Exergy } \\
(\mathbf{k W h})-50 \%\end{array}$ & $\begin{array}{c}\text { Chemical } \\
\text { Exergy } \\
\mathbf{( k W h ) - 3 0 \%}\end{array}$ & $\begin{array}{c}\text { Chemical } \\
\text { Component }\end{array}$ & $\begin{array}{c}\text { Chemical } \\
\text { Exergy } \\
\text { (kWh)-50\% }\end{array}$ & $\begin{array}{c}\text { Chemical } \\
\text { Exergy } \\
\mathbf{( k W h ) - 3 0 \%}\end{array}$ \\
\hline $\mathrm{CH}_{4}(\mathrm{~g})$ & $11,523.72$ & $11,523.72$ & $\mathrm{Zn}$ & 0.23 & 0.05 \\
$\mathrm{O}_{2}(\mathrm{~g})$ & 76.25 & 76.11 & $\mathrm{Fe}$ & 0.03 & 0.02 \\
$\mathrm{~N}_{2}(\mathrm{~g})$ & 52.02 & 51.93 & $\mathrm{Au}$ & 0.21 & 0.13 \\
$\mathrm{Ni}$ (Anode copper stream) & 75.68 & 170.61 & $\mathrm{Ag}$ & 1.46 & 0.95 \\
$\mathrm{~Pb}$ & 6.41 & 12.76 & $\mathrm{In}$ & 0.04 & 0.04 \\
$\mathrm{Cu}(\mathrm{l})$ & 2887.21 & 3731.76 & $\mathrm{Ge}$ & 0.09 & 0.05 \\
$\mathrm{Sn}$ & 78.36 & 44.71 & $\mathrm{Pd}$ & 0.06 & 0.04 \\
\hline
\end{tabular}

Table 8. Exergy values of materials going into the electrorefining stage.

\begin{tabular}{cccccc}
\hline $\begin{array}{c}\text { Chemical } \\
\text { Component }\end{array}$ & $\begin{array}{c}\text { Chemical } \\
\text { Exergy } \\
\text { (kWh)-50\% }\end{array}$ & $\begin{array}{c}\text { Chemical } \\
\text { Exergy } \\
\mathbf{( k W h ) - 3 0 \%}\end{array}$ & $\begin{array}{c}\text { Chemical } \\
\text { Component }\end{array}$ & $\begin{array}{c}\text { Chemical } \\
\text { Exergy } \\
\mathbf{( k W h ) - 5 0 \%}\end{array}$ & $\begin{array}{c}\text { Chemical } \\
\text { Exergy } \\
\mathbf{( k W h ) - 3 0 \%}\end{array}$ \\
\hline $\mathrm{H}_{2} \mathrm{SO}_{4}(\mathrm{l})$ & 191.04 & 242.81 & $\mathrm{C}$ & 113.66 & 113.66 \\
$\mathrm{CuSO}_{4}$ & 38.83 & 57.82 & $\mathrm{Cu}$ & 2887.21 & 3731.76 \\
$\mathrm{H}_{2} \mathrm{O}$ & 30.03 & 37.64 & $\mathrm{Ge}$ & 0.09 & 0.05 \\
$\mathrm{Ni}$ & 48.58 & 77.25 & $\mathrm{In}$ & 0.04 & 0.04 \\
$\mathrm{As}$ & 51.75 & 66.36 & $\mathrm{Ni}$ & 22.70 & 170.61 \\
$\mathrm{Ag}$ & 1.46 & 0.95 & $\mathrm{~Pb}$ & 0.64 & 7.58 \\
$\mathrm{Au}$ & 0.21 & 0.13 & $\mathrm{Pd}$ & 0.06 & 0.04 \\
$\mathrm{Zn}$ & 0.02 & 0.01 & $\mathrm{Sn}$ & 39.18 & 44.71 \\
\hline
\end{tabular}

\subsection{Effect of Metal and Oxide Dust}

For the two proposed scenarios (30 $\mathrm{wt} \%$ and $50 \mathrm{wt} \%$ e-waste in the feed material), the chemical exergy of waste emissions (metal and oxide dust and exhaust gas) and solid waste such as those in slag and solid monoxide are compared in Table 9. As can be seen from the data presented in Table 9, during the smelting of copper scrap and electronic waste in the reduction furnace, the chemical exergy of $822 \mathrm{MJ}$ for metal and oxide dust is calculated for $5.03 \mathrm{t}$ of produced copper, and $10 \mathrm{~kg}$ of gold and silver (for $50 \%$ e-waste in the feed scenario). The quality of the copper scrap melted in the reduction furnace mainly controls the produced dust composition. Common compositional ranges for metal and oxide dust obtained from thermodynamic modeling are presented in Table 9. Table 9 indicates that all of the process units considered in the proposed flowsheet follow a similar trend when the percentage of electronic waste in the feed is decreased.

Comparing the exergy going into the process units and exergy going out of the process unit's values presented in Tables 5-9, the total loss in exergy during the process is revealed to be $45.5 \%$. The exergy losses in the reduction, oxidation, and fire-refining furnaces are caused by chemical reactions and heat transfer. It is of great interest to note that controlling the outlet temperature of liquid copper, slims, and impure electrolyte is of significant importance. The main reason is that the cathode copper contains an exergy value of 10,490 MJ as shown in Table 9. 
Table 9. Exergy values of materials going out of reduction (a), oxidation (b), fire refining (c), and electrorefining $(\mathrm{d})$ furnace on a chemical component basis.

\begin{tabular}{|c|c|c|}
\hline \multicolumn{3}{|c|}{ (a) } \\
\hline Output Streams & \multicolumn{2}{|c|}{ Chemical Ex (kWh) } \\
\hline Metal and Oxide Dust & Chem Ex (kWh)-50\% & Chem Ex (kWh)-30\% \\
\hline Total & 228.33 & 129.82 \\
\hline $\mathrm{Zn}(\mathrm{g})$ & 162.99 & 26.03 \\
\hline $\mathrm{Pb}(\mathrm{g})$ & 13.09 & 59.61 \\
\hline $\operatorname{PbBr}(\mathrm{g})$ & 1.20 & 5.45 \\
\hline $\mathrm{PbO}$ & 0.23 & 1.05 \\
\hline $\mathrm{SnO}$ & 3.82 & 0.19 \\
\hline $\operatorname{HBr}(\mathrm{g})$ & 0.09 & 0.07 \\
\hline $\mathrm{PbS}$ & 0.70 & 4.75 \\
\hline $\mathrm{FeBr}_{2}$ & 0.40 & 2.27 \\
\hline $\mathrm{InBr}$ & 0.06 & 0.03 \\
\hline $\mathrm{GeO}$ & 0.03 & 0.01 \\
\hline SnS & 1.87 & 0.13 \\
\hline $\mathrm{Br}$ & 40.45 & 16.01 \\
\hline $\mathrm{ZnBr}_{2}$ & 0.13 & 0.02 \\
\hline $\mathrm{PbBr}_{2}$ & 0.05 & 0.20 \\
\hline $\mathrm{SnBr}_{2}$ & 3.22 & 0.14 \\
\hline Exhaust Gas & Chem Ex kWh-50\% & Chem Ex (kWh)-30\% \\
\hline Total & 791.40 & 529.56 \\
\hline $\mathrm{CO}_{2}(\mathrm{~g})$ & 269.28 & 180.73 \\
\hline $\mathrm{N}_{2}(\mathrm{~g})$ & 12.21 & 7.20 \\
\hline $\mathrm{CO}(\mathrm{g})$ & 508.42 & 341.24 \\
\hline $\mathrm{H}_{2} \mathrm{O}(\mathrm{g})$ & 0.05 & 0.05 \\
\hline $\mathrm{SO}_{2}(\mathrm{~g})$ & 0.71 & -0.32 \\
\hline $\mathrm{H}_{2}(\mathrm{~g})$ & 0.72 & 0.66 \\
\hline $\mathrm{SO}(\mathrm{g})$ & 0.01 & -0.01 \\
\hline Slag (Reduction) & Chem Ex (kWh)-50\% & Chem Ex (kWh)-30\% \\
\hline Total & 1135.29 & 716.26 \\
\hline $\mathrm{Al}_{2} \mathrm{O}_{3}(\mathrm{l})$ & 491.01 & 288.13 \\
\hline $\mathrm{SiO}_{2}(\mathrm{l})$ & 17.79 & 11.89 \\
\hline $\mathrm{CaO}(\mathrm{l})$ & 45.20 & 45.20 \\
\hline $\mathrm{FeO}(\mathrm{l})$ & 402.06 & 284.07 \\
\hline $\mathrm{Fe}_{2} \mathrm{O}_{3}(\mathrm{l})$ & 0.22 & 0.13 \\
\hline $\mathrm{PbO}(\mathrm{s})$ & 47.41 & 30.95 \\
\hline $\mathrm{ZnO}(\mathrm{s})$ & 29.24 & 40.85 \\
\hline $\mathrm{NiO}(\mathrm{l})$ & 1.32 & 0.87 \\
\hline $\mathrm{SnO}(\mathrm{l})$ & 3.35 & 4.70 \\
\hline $\mathrm{Cu}_{2} \mathrm{O}(\mathrm{l})$ & 96.99 & 9.21 \\
\hline $\mathrm{FeS}(\mathrm{l})$ & 0.27 & 0 \\
\hline $\operatorname{PbS}(1)$ & 0.06 & 0.04 \\
\hline $\mathrm{ZnS}(1)$ & 0.08 & 0.11 \\
\hline $\mathrm{Cu}_{2} \mathrm{~S}(\mathrm{l})$ & 0.06 & 0.01 \\
\hline $\mathrm{AgO}(\mathrm{l})$ & 0.04 & 0 \\
\hline $\mathrm{Ta}(\mathrm{s})$ & 0.18 & 0.11 \\
\hline
\end{tabular}


Table 9. Cont.

\begin{tabular}{|c|c|c|}
\hline Black Copper & Chem Ex (kWh)-50\% & Chem Ex (kWh)-30\% \\
\hline Total & 4221.02 & 5207.51 \\
\hline $\mathrm{Ni}$ & 378.41 & 437.47 \\
\hline $\mathrm{Pb}$ & 64.06 & 86.79 \\
\hline $\mathrm{Cu}(\mathrm{l})$ & 3155.42 & 4056.26 \\
\hline $\mathrm{Sn}$ & 593.65 & 604.12 \\
\hline $\mathrm{Zn}$ & 23.13 & 16.22 \\
\hline $\mathrm{Fe}$ & 4.39 & 5.36 \\
\hline $\mathrm{Au}$ & 0.21 & 0.13 \\
\hline $\mathrm{Ag}$ & 1.49 & 0.96 \\
\hline In & 0.04 & 0.04 \\
\hline $\mathrm{Ge}$ & 0.15 & 0.12 \\
\hline $\mathrm{Pd}$ & 0.06 & 0.04 \\
\hline Solid Spinel Oxide & Chem Ex (kWh)-50\% & Chem Ex (kWh)-30\% \\
\hline Total & 35.96 & 51.91 \\
\hline $\mathrm{NiO}$ & 2.54 & 1.86 \\
\hline $\mathrm{ZnO}$ & 13.35 & 14.01 \\
\hline $\mathrm{Fe}_{3} \mathrm{O}_{4}$ & 10.06 & 7.54 \\
\hline $\mathrm{Al}_{2} \mathrm{O}_{3}$ & 10.02 & 28.50 \\
\hline \multicolumn{3}{|c|}{ (b) } \\
\hline Slag (Oxidation) & Chem Ex (kWh)-50\% & Chem Ex (kWh)-30\% \\
\hline Total & 542.83 & 610.36 \\
\hline $\mathrm{FeO}(\mathrm{l})$ & 26.94 & 22.98 \\
\hline $\mathrm{CaO}(\mathrm{l})$ & 104.93 & 104.93 \\
\hline $\mathrm{SiO}_{2}(\mathrm{l})$ & 3.51 & 3.51 \\
\hline $\mathrm{Fe}_{2} \mathrm{O}_{3}(\mathrm{l})$ & 1.20 & 1.39 \\
\hline $\mathrm{PbO}(\mathrm{s})$ & 7.73 & 13.09 \\
\hline $\mathrm{ZnO}(\mathrm{s})$ & 1.78 & 1.27 \\
\hline $\mathrm{NiO}(\mathrm{l})$ & 34.14 & 26.41 \\
\hline $\mathrm{SnO}(\mathrm{l})$ & 241.99 & 290.88 \\
\hline $\mathrm{Cu}_{2} \mathrm{O}(\mathrm{l})$ & 120.58 & 145.89 \\
\hline $\mathrm{AgO}(1)$ & 0.03 & 0.00 \\
\hline Exhaust & Chem Ex (kWh)-50\% & Chem Ex (kWh)-30\% \\
\hline Total & 958.36 & 958.24 \\
\hline $\mathrm{CO}_{2}(\mathrm{~g})$ & 818.75 & 818.75 \\
\hline $\mathrm{N}_{2}(\mathrm{~g})$ & 25.09 & 24.98 \\
\hline $\mathrm{CO}(\mathrm{g})$ & 114.51 & 114.51 \\
\hline Metal and Oxide Dust (Oxidation) & Chem Ex (kWh) & Chem Ex (kWh)-30\% \\
\hline Total & 14.92 & 16.43 \\
\hline $\mathrm{Zn}$ & 1.16 & 0.25 \\
\hline $\mathrm{Pb}$ & 6.73 & 4.39 \\
\hline $\mathrm{PbO}$ & 5.07 & 4.41 \\
\hline $\mathrm{SnO}$ & 1.95 & 7.37 \\
\hline $\mathrm{GeO}$ & 0.01 & 0.01 \\
\hline Solid Monoxide (oxidation) & Chem Ex (kWh)-50\% & Chem Ex (kWh)-30\% \\
\hline Total & 12.91 & 11.74 \\
\hline $\mathrm{Fe}_{3} \mathrm{O}_{4}$ & 0.88 & 0.85 \\
\hline $\mathrm{ZnO}$ & 0.02 & 0.05 \\
\hline $\mathrm{NiO}$ & 6.93 & 9.79 \\
\hline $\mathrm{SnO}_{2}$ & 5.07 & 1.05 \\
\hline
\end{tabular}


Table 9. Cont.

\begin{tabular}{ccc}
\hline Anode Copper to FR (Fire Refining) & Chem Ex (kWh) -50\% & Chem Ex (kWh)-30\% \\
\hline Total & 3049.79 & 3961.13 \\
\hline $\mathrm{Ni}$ & 75.68 & 170.61 \\
$\mathrm{~Pb}$ & 6.41 & 12.76 \\
$\mathrm{Cu}(\mathrm{l})$ & 2887.21 & 3731.76 \\
$\mathrm{Sn}$ & 78.36 & 44.71 \\
$\mathrm{Zn}$ & 0.23 & 0.05 \\
$\mathrm{Fe}$ & 0.03 & 0.02 \\
$\mathrm{Au}$ & 0.21 & 0.13 \\
$\mathrm{Ag}$ & 1.46 & 0.95 \\
$\mathrm{In}$ & 0.04 & 0.04 \\
$\mathrm{Ge}$ & 0.09 & 0.05 \\
$\mathrm{Pd}$ & 0.06 & 0.04 \\
\hline
\end{tabular}

(c)

\begin{tabular}{ccc}
\hline Off Gas & Chem Ex (kWh)-50\% & Chem Ex (kWh)-30\% \\
\hline Total & 3956.67 & 3881.38 \\
\hline $\mathrm{H}_{2}(\mathrm{~g})$ & 1334.30 & 1334.30 \\
$\mathrm{Co}(\mathrm{g})$ & 0.00 & 0.00 \\
$\mathrm{H}_{2} \mathrm{O}(\mathrm{g})$ & 15.52 & 15.52 \\
$\mathrm{CO}_{2}(\mathrm{~g})$ & 215.75 & 215.75 \\
$\mathrm{~Pb}$ & 5.77 & 5.18 \\
$\mathrm{Zn}$ & 0.21 & 0.05 \\
$\mathrm{CH}_{4}(\mathrm{~g})$ & 2258.65 & 2258.65 \\
$\mathrm{SnO}_{(\mathrm{g})}$ & 21.44 & 0.00 \\
$\mathrm{Ni}$ & 52.98 & 0.00 \\
$\mathrm{Fe}$ & 0.03 & 0.00 \\
$\mathrm{~N}_{2}(\mathrm{~g})$ & 52.02 & 51.93 \\
\hline
\end{tabular}

\begin{tabular}{ccc}
\hline Anode Cu to ER (Electro Refining) & Chem Ex (kWh)-50\% & Chem Ex (kWh)-30\% \\
\hline Total & 3065.28 & 4069.55 \\
\hline $\mathrm{Ag}$ & 1.46 & 0.95 \\
$\mathrm{Au}$ & 0.21 & 0.13 \\
$\mathrm{C}$ & 113.66 & 113.66 \\
$\mathrm{Cu}$ & 2887.21 & 3731.76 \\
$\mathrm{Ge}$ & 0.09 & 0.05 \\
$\mathrm{In}$ & 0.04 & 0.04 \\
$\mathrm{Ni}$ & 22.70 & 170.61 \\
$\mathrm{~Pb}$ & 0.64 & 7.58 \\
$\mathrm{Pd}$ & 0.06 & 0.04 \\
$\mathrm{Sn}$ & 39.18 & 44.71 \\
$\mathrm{Zn}$ & 0.02 & 0.01 \\
\hline
\end{tabular}

(d)

\begin{tabular}{ccc}
\hline Impure Electrolyte & Chem Ex (kWh) -50\% & Chem Ex (kWh)-30\% \\
\hline Total & 545.72 & 833.19 \\
\hline $\mathrm{H}_{2} \mathrm{O}$ & 29.62 & 37.02 \\
$\mathrm{H}_{2} \mathrm{SO}_{4}$ & 263.40 & 350.21 \\
$\mathrm{Ni}$ & 69.86 & 242.91 \\
$\mathrm{As}$ & 38.81 & 49.77 \\
$\mathrm{C}$ & 113.66 & 113.66 \\
$\mathrm{Cu}$ & 29.46 & 38.19 \\
$\mathrm{~Pb}$ & 0.01 & 0.02 \\
$\mathrm{Zn}$ & 0.02 & 0.01 \\
$\mathrm{O}_{2}(\mathrm{~g})$ & 0.88 & 1.32 \\
\hline
\end{tabular}


Table 9. Cont.

\begin{tabular}{ccc}
\hline Slimes & Chem Ex (kWh) & \\
\hline Total & 58.27 & 31.60 \\
\hline $\mathrm{Ag}$ & 1.46 & 0.95 \\
$\mathrm{Au}$ & 0.21 & 0.13 \\
$\mathrm{Cu}$ & 2.95 & 0.00 \\
$\mathrm{Ge}$ & 0.09 & 0.05 \\
$\mathrm{In}$ & 0.04 & 0.04 \\
$\mathrm{Ni}$ & 0.71 & 2.48 \\
$\mathrm{~Pb}$ & 0.63 & 7.50 \\
$\mathrm{Pd}$ & 0.06 & 0.04 \\
$\mathrm{Sn}$ & 39.18 & 0.00 \\
$\mathrm{As}$ & 12.94 & 16.59 \\
\hline Cathode Cu 99.9\% & Chem Ex (kWh)-50\% & Chem Ex (kWh)-30\% \\
\hline Total & 2914.09 & 3825.45 \\
\hline $\mathrm{Cu}$ & 2913.37 & 3776.96 \\
$\mathrm{Ni}$ & 0.71 & 2.48 \\
\hline
\end{tabular}

\subsection{Effect of Off-Gas Emission}

Figure 6 shows the emission exergy based on the waste gas types for the e-waste processing through copper recycling with 50\% and 30\% e-waste (waste PCBs) in the feed during the period of one hour. As can be perceived from Figure 6, the values of emission exergy for exhaust gas $\left(\mathrm{CO}, \mathrm{NO}_{\mathrm{x}}\right.$, and $\mathrm{SO}_{2}$ ) enhanced by 1.94 and 5.64 times in the oxidation and fire-refining stages in comparison to the reduction stage, respectively in a $50 \%$ e-waste scenario and by 3.13 and 5.66 times in a $30 \%$ e-waste scenario.

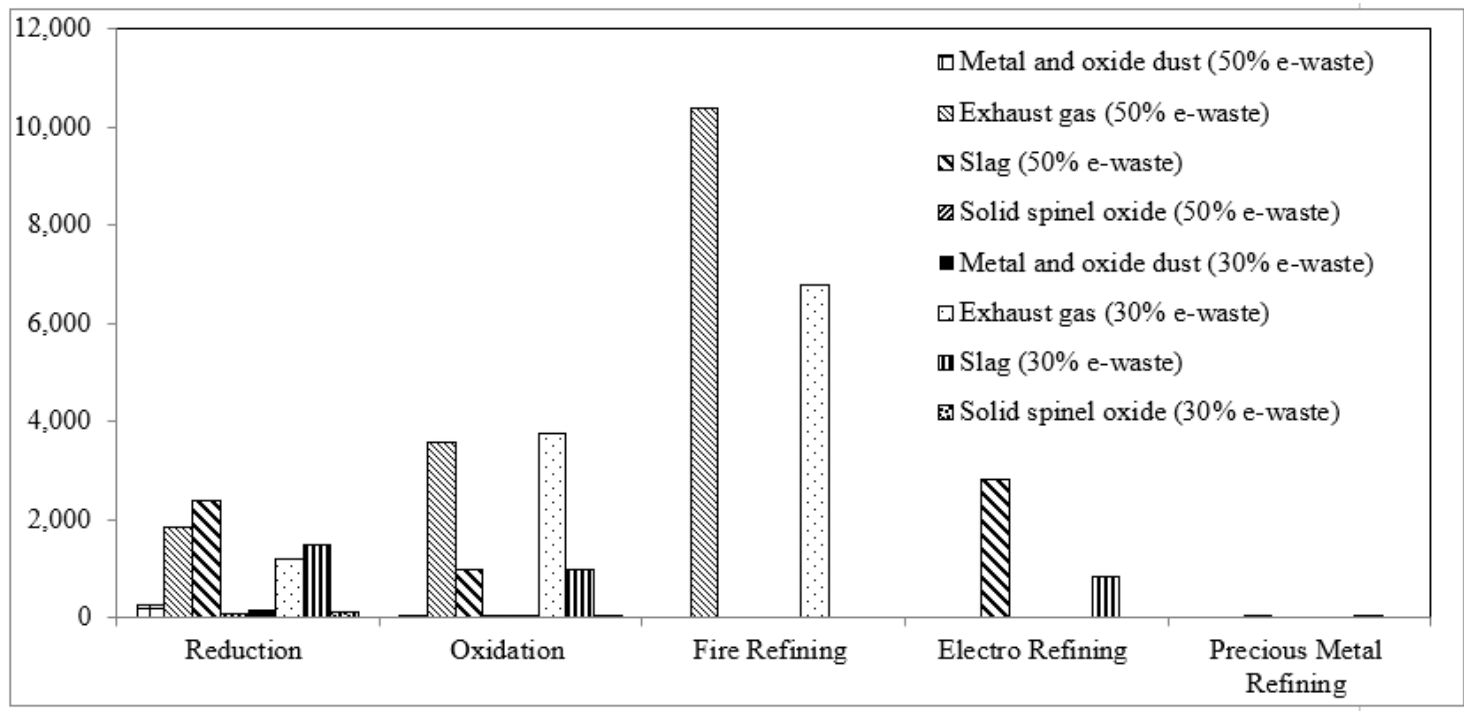

Figure 6. Emission exergy based on waste gas (50\% and 30\% e-waste in the feed).

The rate of the waste gas emission of each process unit is depicted in Figure 7. $\mathrm{CO}_{2}$ has the foremost contribution with a rate enlarged from approximately $18 \%$ to more than $69 \%$ from the reduction to the oxidation stage in the $30 \%$ e-waste in the feed scenario, and from $21 \%$ to $63 \%$ in the $50 \%$ e-waste scenario, respectively. 


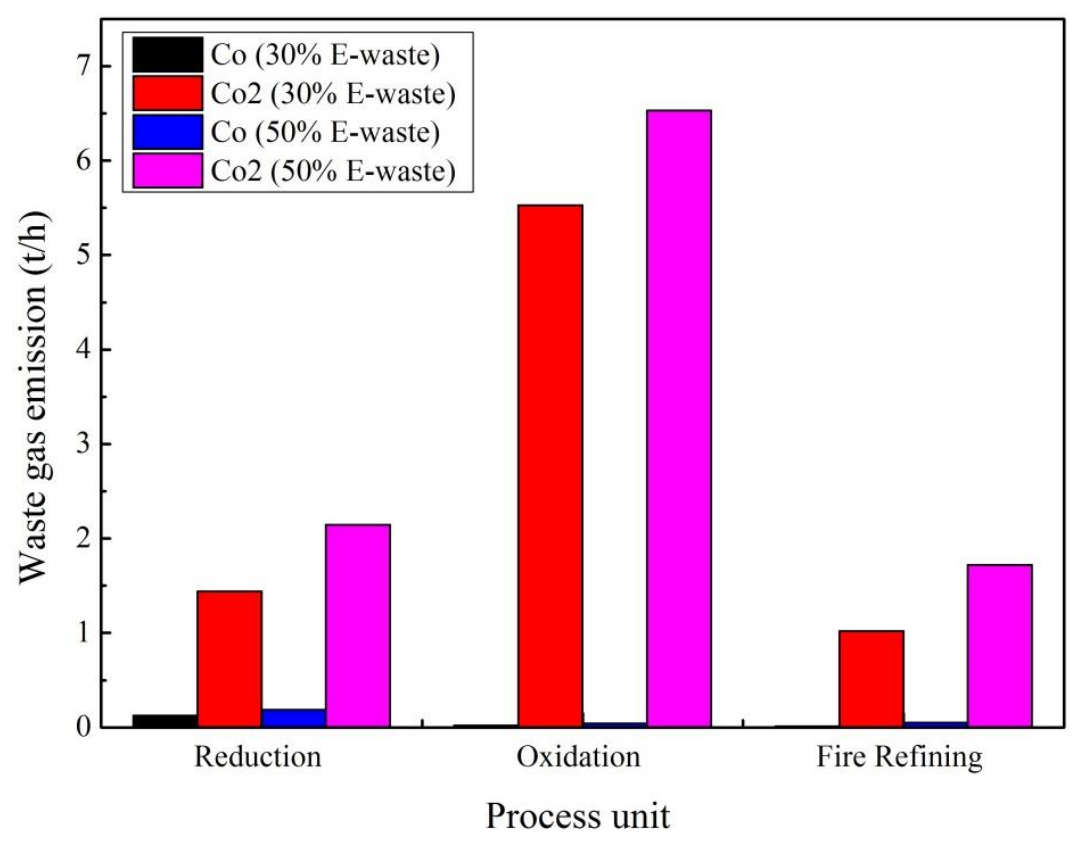

Figure 7. Waste gas emission rate $(\mathrm{t} / \mathrm{h})$.

Figure 8 made a comparison between the solid and gas waste emission generated by the two major process units (reduction and oxidation furnace) in e-waste treatment.

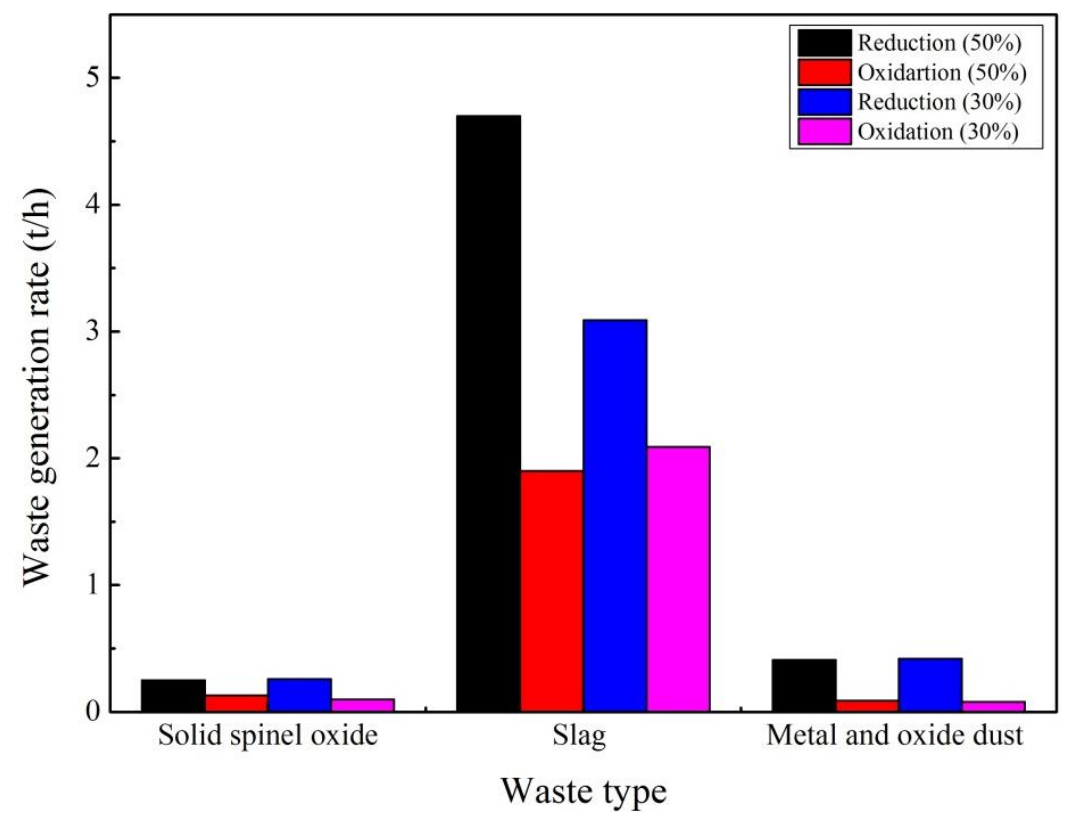

Figure 8. Solid waste generation rate $(t / h)$.

As can be seen from Figure 8, it is estimated that almost $2200 \mathrm{t}$ of solid spinel oxide dust, $41,000 \mathrm{t}$ of slag, and $3600 \mathrm{t}$ of metal and oxide dust was generated annually in the reduction furnace when the percentage of e-waste in the feed is $50 \mathrm{wt} \%$.

From this, $3000 \mathrm{t}$ was further recycled to recover $\mathrm{Ni}$, Sn, etc., and slag was partially reused in a closed loop back to the reduction and oxidation furnaces, with the rest being landfilled.

The variation of the exergy loss for all of the process units involved in e-waste treatment through secondary copper smelting is presented in Figure 9. The oxidation stage is the key contributor for exergy loss followed by reduction and fire refining. As depicted in Figure 9, the exergy losses dropped 
down sharply from the reduction to oxidation furnaces, and then escalated and slowed down during the precious metal-refining stage.

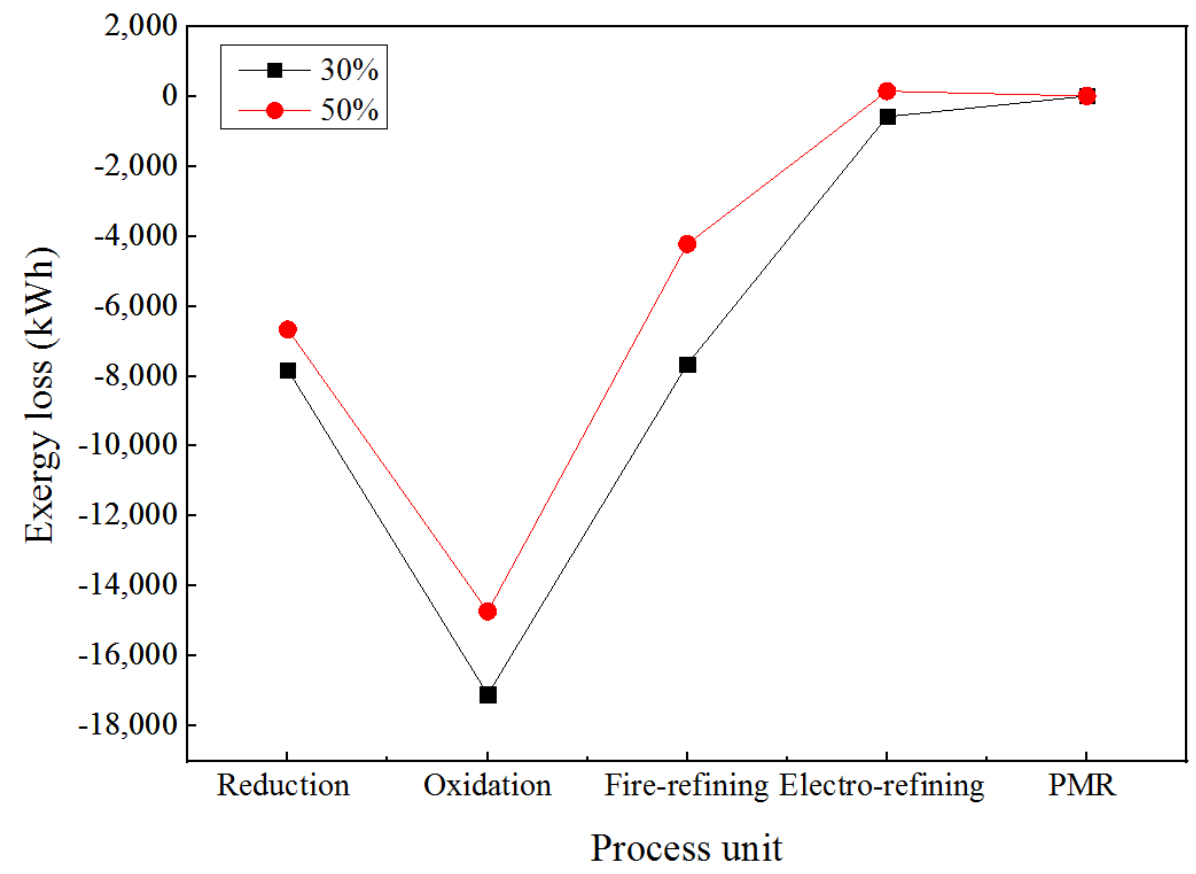

Figure 9. Exergy losses for different percentages of e-waste in the feed material.

The exergy efficiency of the five process units involved in the e-waste treatment through the secondary copper recycling process is shown in Figure 10. As can be seen from this figure, the precious metal refining (PMR) has the largest exergy efficiency followed by electrorefining and fire refining.

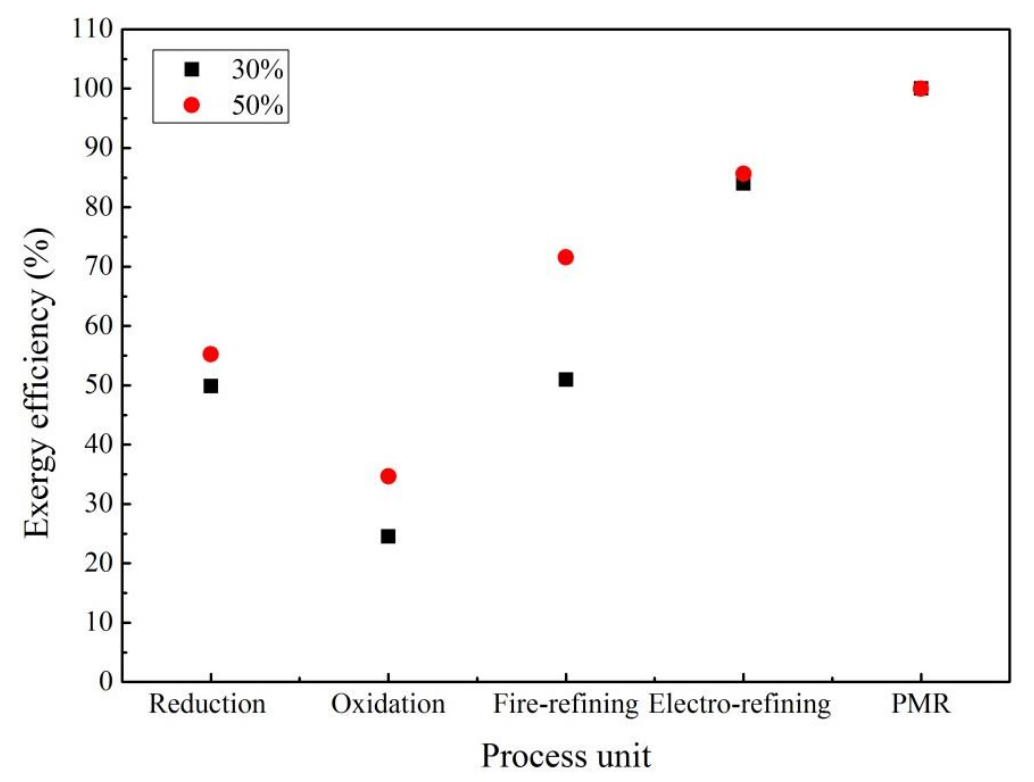

Figure 10. Exergy efficiency for different percentage of e-waste in the feed material.

\subsection{Effect of Solid Waste in Slag}

The exergy content of the two process streams was estimated and shown in Figure 11. As can be seen from this figure, the chemical exergy of the solid waste elements in slag has decreased noticeably by decreasing the e-waste percentage in the feed in the reduction process; however, the decrease is negligible in the oxidation process. 


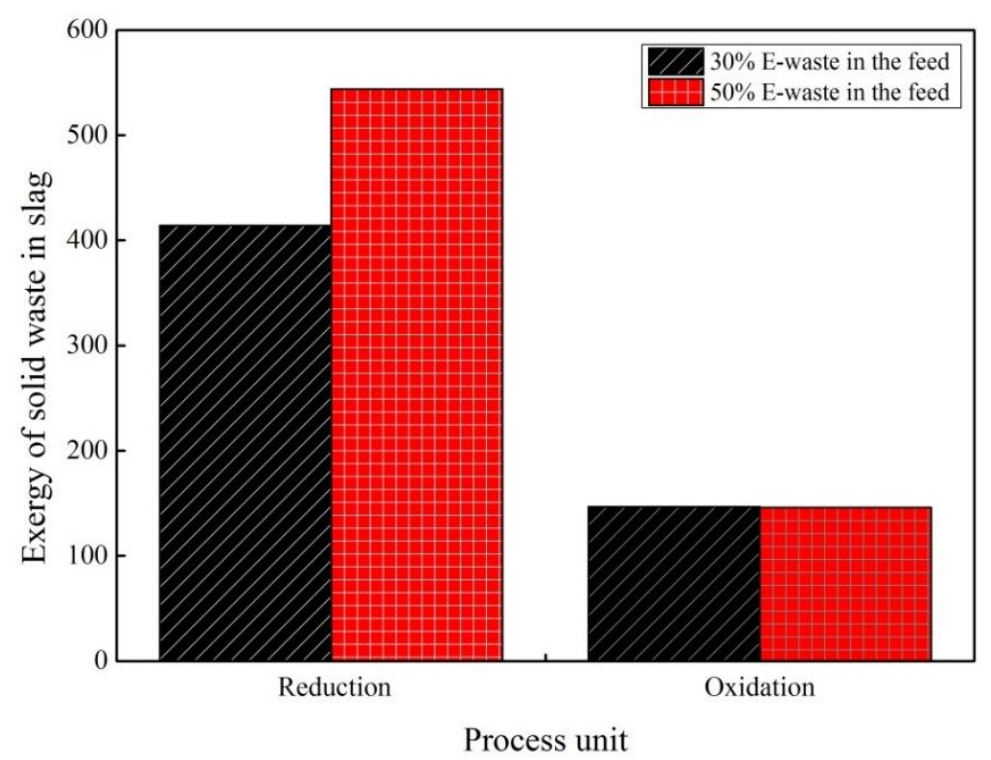

Figure 11. Effect of solid waste in slag on chemical exergy for two scenarios.

In order to understand the losses and performance of the proposed process for the two scenarios investigated in this study, a comparison has been made based on the environmental footprint and exergy losses of the flowsheets. The emphasis is more on the quantity of exhaust gas emitted from the process. From the results, it is evident that the " $30 \%$ e-waste in-feed" scenario is superior to the " $50 \%$ e-waste in-feed", as the amount of exhaust gas is about $34 \%$ less. On the other hand, as higher exergy loss is corresponded to a higher usage of coke and hence a higher environmental burden, once again, the $30 \%$ e-waste in the feed scenario is considered as a preferable option.

\section{Conclusions}

An exergy analysis for electronic waste treatment through a secondary copper-smelting route is thermodynamically modeled using HSC chemistry. The suggested technique has been employed to estimate the loss of exergy within the proposed precious metal recovery system, and helps calculate and assess the exergy efficiency for a different percentage of e-waste in the feed material. The results of the two case studies assessed here indicated that the value of emission exergy for exhaust gas (CO, $\mathrm{NO}_{\mathrm{x}}$, and $\mathrm{SO}_{2}$ ) is enhanced in the oxidation and fire-refining stages in comparison to the reduction stage for both scenarios (50\% and 30\% e-waste in the feed). Moreover, by comparing the rate of the waste gas emission of each process unit, it has been revealed that $\mathrm{CO}_{2}$ is the main contributor, with a sharp increasing rate from the reduction stage to the oxidation stage for both $30 \mathrm{wt} \%$ and 50 $w t \%$ e-waste in the material throughput. The variation of the exergy loss for all of the process units involved in e-waste treatment through secondary copper smelting has illustrated that the oxidation stage is the key contributor for exergy loss, followed by reduction and fire refining. In terms of exergy efficiency, precious metal refining (PMR) was found to have the highest exergy efficiency, followed by electrorefining and fire refining.

Further research has to be done to highlight the link between exergy analysis and economics of the metal recovery from waste PCB through the black copper smelting process. That makes the proposed recovery process more widely applicable for the recycling industry. Developing design tools to conduct a systematic study on the relations between exergy, material consumption, and life cycle assessment indicators is a second major area that needs further investigation. Understanding the human footprint and challenges of reaching a circular economy system is a topic of great interest. Further work has to be done to link the proposed recovery process to platinum group metal recovery using black copper smelting. This will allow an accurate assessment of the exergy destruction of compound product designs, including primary production, and hence accommodates the broad circular economy system. 
Author Contributions: The research presented in this paper was a collaborative effort made by all the authors. All the authors contributed to the conceptualization, methodology, Software, validation, formal analysis, investigation, resources, data curation, writing and reviewing.

Funding: This research was funded by Centre for Infrastructure Engineering, Western Sydney University.

Conflicts of Interest: The authors declare no conflict of interest.

\section{References}

1. Rosen, M.A.; Dincer, I. On Exergy and Environmental Impact. Int. J. Energy Res. 1997, 21, 643-654. [CrossRef]

2. Szargut, J.; Morris, D.R.; Steward, F.R. Exergy Analysis of Thermal, Chemical, and Metallurgical Processes; Hemisphere Publishing Corporation: New York, NY, USA, 1988.

3. Edgerton, R.H. Available Energy and Environmental Economics; D.C. Heath: Toronto, Canada, 1982.

4. Ayres, R.U.; Ayres, L.W.; Martinas, K. Eco-Thermodynamics: Exergy and Life Cycle Analysis; INSEAD: Fontainebleau, France, 1996; Volume 19.

5. Ayres, R.U.; Ayres, L.W.; Martinás, K. Exergy, waste accounting, and life-cycle analysis. Energy 1998, 23, 355-363. [CrossRef]

6. Ayres, R.U.; Ayres, L.W.; Warr, B. Is the US economy dematerializing? Main indicators and drivers. In Economics of Industrial Ecology: Materials; Structural Change and Spatial Scales MIT Press: Cambridge, MA, USA, 2004.

7. Rosen, M.A.; Dincer, I.; Kanoglu, M. Role of exergy in increasing efficiency and sustainability and reducing environmental impact. Energy Policy 2008, 36, 128-137. [CrossRef]

8. Rosen, M.A.; Dincer, I. Exergy-Cost-Energy-Mass analysis of thermal systems and processes. Energy Convers. Manag. 2003, 44, 1633-1651. [CrossRef]

9. Daniel, J.J.; Rosen, M.A. Exergetic environmental assessment of life cycle emissions for various automobiles and fuels. Exergy Int. J. 2002, 2, 283-294. [CrossRef]

10. Dincer, I. Thermodynamics, Exergy and Environmental Impact. Energy Sources 2000, 22, 723-732. [CrossRef]

11. Dincer, I. The role of exergy in energy policy making. Energy Policy 2002, 30, 137-149. [CrossRef]

12. Dincer, I. Technical, environmental and exergetic aspects of hydrogen energy systems. Int. J. Hydrogen Energy 2002, 27, 265-285. [CrossRef]

13. Crane, P.; Scott, D.; Rosen, M. Comparison of exergy of emissions from two energy conversion technologies, considering the potential for environmental impact. Int. J. Hydrogen Energy 1992, 17, 345-350. [CrossRef]

14. Creyts, J.C. Extended Exergy Analysis: A Tool for Assessment of the Environmental Impact of Industrial Processes; University of California: Berkeley, CA, USA, 1998.

15. Gong, M.; Wall, G. On exergy and sustainable development-Part 2: Indicators and methods. Exergy Int. J. 2001, 1, 217-233. [CrossRef]

16. Ukidwe, N.U.; Bakshi, B.R. Thermodynamic Accounting of Ecosystem Contribution to Economic Sectors with Application to 1992 U.S. Economy. Environ. Sci. Technol. 2004, 38, 4810-4827. [CrossRef] [PubMed]

17. Ukidwe, N.U.; Bakshi, B.R. Industrial and ecological cumulative exergy consumption of the United States via the 1997 input-output benchmark model. Energy 2007, 32, 1560-1592. [CrossRef]

18. Ji, X.; Chen, G.Q.; Chen, B.; Jiang, M.M. Exergy-based assessment for waste gas emissions from Chinese transportation. Energy Policy 2009, 37, 2231-2240. [CrossRef]

19. Chen, G.Q. Scarcity of exergy and ecological evaluation based on embodied exergy. Commun. Nonlinear Sci. Numer. Simul. 2006, 11, 531-552. [CrossRef]

20. Dincer, I.; Rosen, M.A. Thermodynamic aspects of renewables and sustainable development. Renew. Sustain. Energy Rev. 2005, 9, 169-189. [CrossRef]

21. Ayres, R.U.; Ayres, L.W.; Martinas, K. Eco-Thermodynamics: Exergy and Life Cycle Analysis. 1996. Available online: https:/ / flora.insead.edu/fichiersti_wp/inseadwp1996/96-04.pdf (accessed on 4 April 2019).

22. Amini, S.H.; Remmerswaal, J.A.M.; Castro, M.B.; Reuter, M.A. Quantifying the quality loss and resource efficiency of recycling by means of exergy analysis. J. Clean. Prod. 2007, 15, 907-913. [CrossRef]

23. Ignatenko, O.; van Schaik, A.; Reuter, M.A. Exergy as a tool for evaluation of the resource efficiency of recycling systems. Miner. Eng. 2007, 20, 862-874. [CrossRef]

24. Castro, M.B.G.; Remmerswaal, J.A.M.; Brezet, J.C.; Reuter, M.A. Exergy losses during recycling and the resource efficiency of product systems. Resour. Conserv. Recycl. 2007, 52, 219-233. [CrossRef] 
25. Ghodrat, M.; Rhamdhani, M.A.; Khaliq, A.; Brooks, G.; Samali, B. Thermodynamic analysis of metals recycling out of waste printed circuit board through secondary copper smelting. J. Mater. Cycles Waste Manag. 2017, 20, 386-401. [CrossRef]

26. Bale, C.W.; Bélisle, E.; Chartrand, P.; Decterov, S.A.; Eriksson, G.; Hack, K.; Jung, I.-H.; Kang, Y.-B.; Melançon, J.; Pelton, A.D.; et al. FactSage thermochemical software and databases-Recent developments. Calphad 2009, 33, 295-311. [CrossRef]

27. Cornelissen, R.L. Thermodynamics and sustainable development. In The Use of Exergy Analysis and the Reduction of Irreversibility; Universiteit Twente: Enschede, The Netherlands, 1997; ISBN 9036510538.

28. Hait, J.; Jana, R.K.; Sanyal, S.K. Processing of copper electrorefining anode slime: A review. Miner. Process. Extr. Metall. 2009, 118, 240-252. [CrossRef]

29. Kulczycka, J.; Lelek, .; Lewandowska, A.; Wirth, H.; Bergesen, J.D. Environmental impacts of energy-efficient pyrometallurgical copper smelting technologies: The consequences of technological changes from 2010 to 2050. J. Ind. Ecol. 2016, 20, 304-316. [CrossRef]

30. Forsén, O.; Aromaa, J.; Lundström, M. Primary Copper Smelter and Refinery as a Recycling Plant-A System Integrated Approach to Estimate Secondary Raw Material Tolerance. Recycling 2017, 2, 19. [CrossRef]

31. Klemettinen, L.; Avarmaa, K.; O’Brien, H.; Taskinen, P.; Jokilaakso, A. Behavior of Tin and Antimony in Secondary Copper Smelting Process. Minerals 2019, 9, 39. [CrossRef]

32. Ghodrat, M.; Rhamdhani, M.A.; Brooks, G.; Masood, S.; Corder, G. Techno economic analysis of electronic waste processing through black copper smelting route. J. Clean. Prod. 2016, 126, 178-190. [CrossRef]

(C) 2019 by the authors. Licensee MDPI, Basel, Switzerland. This article is an open access article distributed under the terms and conditions of the Creative Commons Attribution (CC BY) license (http:/ / creativecommons.org/licenses/by/4.0/). 